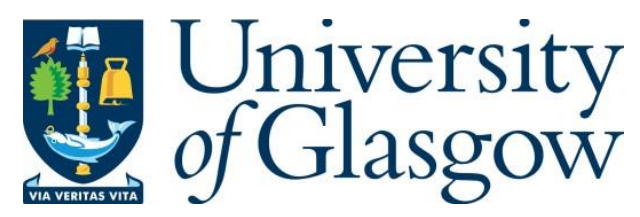

Williams, B. et al. (2018) 2018 Practice guidelines for the management of arterial hypertension of the European Society of Hypertension (ESH) and the European Society of Cardiology (ESC). Blood Pressure, 27(6), pp. 314-340.

There may be differences between this version and the published version. You are advised to consult the publisher's version if you wish to cite from it.

http://eprints.gla.ac.uk/173246/

Deposited on: 8 January 2019

Enlighten - Research publications by members of the University of Glasgow http://eprints.gla.ac.uk 


\title{
2018 Practice guidelines for the management of arterial hypertension of the European Society of Hypertension (ESH) and the European Society of Cardiology (ESC)
}

\section{ESH/ESC Task Force for the Management of Arterial Hypertension}

\author{
List of authors/Task Force members \\ Bryan Williams (ESC Chairperson) (UK), Giuseppe Mancia (ESH Chairperson) (Italy), \\ Wilko Spiering (The Netherlands), Enrico Agabiti Rosei (Italy), Michel Azizi (France), Michel \\ Burnier (Switzerland), Denis Clement (Belgium), Antonio Coca (Spain), Giovanni De Simone (Italy), \\ Anna Dominiczak (UK), Thomas Kahan (Sweden), Felix Mahfoud (Germany), Josep Redon (Spain), \\ Luis Ruilope (Spain), Alberto Zanchetti †, Mary Kerins (Ireland), Sverre Kjeldsen (Norway), \\ Reinhold Kreutz (Germany), Stephane Laurent (France), Gregory Y. H. Lip(UK), Richard Mcmanus \\ (UK), Krzysztof Narkiewicz (Poland), Frank Ruschitzka (Switzerland),Roland Schmieder (Germany), \\ Evgeny Shlyakhto (Russia), Konstantinos Tsioufis (Greece),Victor Aboyans (France), Ileana \\ Desormais (France).
}

ESH Practice Guidelines writing Task Force

Michel Burnier, Sverre E. Kjeldsen, Guido Grassi, Krzysztof Narkiewicz, Gianfranco Parati, Reinhold Kreutz, Konstantinos Tsioufis, Bryan Williams, Giuseppe Mancia.

$†$ Professor Zanchetti died during the development of these Guidelines, in March 2018. He contributed fully to the redaction of these Guidelines, as a member of the Guidelines' Task Force and as a section co-ordinator. He will be sadly missed by colleagues and friends.

Short Title: 2018 Practice Guidelines for the management of hypertension

Key words: Blood Pressure - Blood pressure measurement - Blood pressure treatment thresholds and targets - Hypertension-mediated organ damage - Lifestyle interventions - Drug therapy - Combination therapy - Device therapy - Secondary hypertension- Special conditions- Adherence

Correspondence to:

Prof. Michel Burnier

Service of Nephrology and Hypertension

Rue du Bugnon 17

1011 Lausanne, Switzerland

Email:michel.burnier@chuv.ch 


\section{List of abbreviations}

ABI, ankle-brachial index;

ABPM,ambulatory blood pressure monitoring;

$\mathrm{ACE}$, angiotensin-converting enzyme;

ACEi, angiotensin-converting enzyme inhibitor;

ACR, albumin:creatinine ratio;

AF, Atrial fibrillation;

$\mathrm{ARB}$, angiotensin receptor blocker;

$\mathrm{AV}$, atrioventricular;

$\mathrm{BP}$, blood pressure;

bpm, beats per minute;

BSA, body surface area;

CAD, coronary artery disease;

CKD, chronic kidney disease;

CVD, cardiovascular disease;

DHP, dihydropyridine;

eGFR, estimated glomerular filtration rate;

ESC, European Society of Cardiology;

ESH, European Society of Hypertension;

HbA1c, Haemoglobin A1c;

HBPM, Home blood pressure monitoring;

HDL-C, HDL-cholesterol;

$\mathrm{HFpEF}$, heart failure with preserved ejection fraction;

$\mathrm{HFrEF}$, heart failure with reduced ejection fraction;

HMOD, Hypertension mediated organ damage;

IMT, intima-media thickness;

LDLC, LDL cholesterol;

LEAD, lower extremity artery disease;

LV, left ventricular;

LVH, left ventricular hypertrophy;

MAP, mean arterial pressure;

MI, myocardial infarction;

MR, magnetic resonance;

MRA, mineralocorticoid receptor antagonist;

MUCH, Masked uncontrolled hypertension;

NTproBNP, N-terminal pro-B natriuretic peptide;

o.d., omni die (every day);

PAC, plasma aldosterone concentration;

PAD, peripheral artery disease;

PRA, plasma renin activity;

PRC, plasma renin concentration;

PWV, pulse wave velocity;

RAS, renin-angiotensin system;

RCT, randomized controlled trial;

RWT, relative wall thickness;

SPC, single-pill combination;

SUCH, sustained uncontrolled hypertension;

TIA, transient ischaemic attack;

TE, transthoracic echocardiography;

WUCH, white coat uncontrolled hypertension 


\section{Summary:}

\section{The key messages in 20 points}

1. Blood pressure, epidemiology, and risk. Globally, over 1 billion people have hypertension. As populations age and adopt more sedentary lifestyles, the worldwide prevalence of hypertension will continue to rise towards 1.5 billion by 2025 . Elevated BP is the leading global contributor to premature death, accounting for almost 10 million deaths in 2015, 4.9 million due to ischaemic heart disease and 3.5 million due to stroke. Hypertension is also a major risk factor for heart failure, AF, CKD, PAD, and cognitive decline.

2. Definition of hypertension. The classification of BP and the definition of hypertension is unchanged from previous European guidelines, and is defined as an office SBP $\geq 140$ and/or DBP $\geq 90 \mathrm{mmHg}$, which is equivalent to a $24-\mathrm{h}$ ABPM average of $\geq 130 / 80 \mathrm{mmHg}$, or a HBPM average $\geq 135 / 85 \mathrm{mmHg}$.

3. Screening and diagnosis of hypertension. Hypertension is usually asymptomatic (hence the term "silent killer"). Because of its high prevalence, screening programmes should be established to ensure that BP is measured in all adults, at least every 5 years and more frequently in people with a high-normal BP. When hypertension is suspected because of an elevated screening BP, the diagnosis of hypertension should be confirmed either by repeated office BP measurements, over a number of visits, or by out-ofoffice BP measurement using 24-h ABPM or by HBPM.

\section{The importance of cardiovascular risk assessment and detection of HMOD.}

Other CV risk factors such as dyslipidaemia and metabolic syndrome frequently cluster with hypertension. Thus, unless the patient is already at high or very high risk due to established CVD, formal $\mathrm{CV}$ risk assessment is recommended using the SCORE system. It is important to recognise, however, that the presence of HMOD, especially LVH, CKD, or advanced retinopathy, further increases the risk of CV morbidity and mortality, and should be screened for as part of risk assessment in hypertensive patients because the SCORE system alone may underestimate their risk.

5. Think - could this patient have secondary hypertension? For most people with hypertension, no underlying cause will be detected. Secondary (and potentially remediable) causes of hypertension are more likely to be present in people with young onset of hypertension $(<40$ years), people with severe or treatment-resistant hypertension, or people who suddenly develop significant hypertension in midlife on a background of previously normal BP. Such patients should be referred for specialist evaluation.

6. Treatment of hypertension - importance of lifestyle interventions. The treatment of hypertension involves lifestyle interventions and drug therapy. Many patients with hypertension will require drug therapy, but lifestyle interventions are important because they can delay the need for drug treatment or complement the BP-lowering effect of drug treatment. Moreover, lifestyle interventions such as sodium restriction, alcohol moderation, healthy eating, regular exercise, weight control and smoking cessation, all have health benefits beyond their impact on blood pressure.

7. When to consider drug treatment of hypertension. The treatment thresholds for hypertension are now less conservative than they were in previous guidelines. We now recommend that patients with low-moderate risk grade 1 hypertension (office BP 140-159/90-99), even if they do not have HMOD, 
should now receive drug treatment if their BP is not controlled after a period of lifestyle intervention alone. For higher risk patients with grade 1hypertension, including those with HMOD, or patients with higher grades of hypertension (e.g. grade 2 hypertension, $\geq 160 / 100 \mathrm{mmHg}$ ), we recommend initiating drug treatment alongside lifestyle interventions. These recommendations apply to all adults up to the age of 80 years.

8. Special considerations in frail and older patients. It is increasingly recognised that biological rather than chronological age, as well as consideration of frailty and independence, are important determinants of the tolerability of and likely benefit from BP-lowering medications. It is important to note that even in the very old (i.e. > 80 years), BP-lowering therapy reduces mortality, stroke, and heart failure. Thus, these patients should not be denied treatment, or have treatment withdrawn simply on the basis of age. For people $>80$ years who have not yet received treatment for their BP, treatment is recommended when their office SBP is $\geq 160 \mathrm{mmHg}$, provided that the treatment is well tolerated.

9. How low should SBP be lowered? This has been a hotly debated topic. A key discussion point is the balance of potential benefits versus potential harm or adverse effects. This is especially important whenever BP targets are lowered, as there is a greater potential for harm to exceed benefit. Thus, in this guideline, we recommend a target range. The evidence strongly suggests that lowering office SBP to < $140 \mathrm{mmHg}$ is beneficial for all patient groups, including independent older patients. There is also evidence to support targeting SBP to $130 \mathrm{mmHg}$ for most patients, if tolerated. Even lower SBP levels $(<130 \mathrm{mmHg}$ ) will be tolerated and potentially beneficial for some patients, especially to further reduce the risk of stroke. SBP should not be targeted to below $120 \mathrm{mmHg}$ because the balance of benefit versus harm becomes concerning at these levels of treated SBP.

10. BP targets in old and very old patient. As discussed above, independence, frailty, and comorbidities will all influence treatment decisions, especially in older ( $\geq 65$ years) and very old $(>80$ years) patients. The desired SBP target range for all patients aged $>65$ years is $<140 \mathrm{mmHg}$ but not $<$ $130 \mathrm{mmHg}$. This is lower than in previous guidelines and may not be achievable in all older patients, but any BP lowering towards this target is likely to be beneficial provided that the treatment is well tolerated.

11. BP targets in patients with diabetes and/or CKD. The BP-treatment targets for patients with diabetes or kidney disease have been a moving target in previous guidelines because of seemingly contradictory results from major outcome trials and meta-analyses. For diabetes, targeting the SBP to < $140 \mathrm{mmHg}$ and towards $130 \mathrm{mmHg}$, as recommended for all other patient groups, is beneficial on major outcomes. Moreover, targeting SBP to $<130 \mathrm{mmHg}$, for those who will tolerate it, may further reduce the risk of stroke but not other major outcomes. SBP should not be lowered below $120 \mathrm{mmHg}$. For patients with CKD, the evidence suggests that the target $\mathrm{BP}$ range should be $<140 \mathrm{mmHg}$ but not $<130$ mmHg.

12. How low should DBP be lowered? The optimal DBP target has been less well defined, but a DBP target of $<80 \mathrm{mmHg}$ is recommended. Some patients with stiff arteries and isolated systolic hypertension will already have DBP levels below this target. These are high risk patients and the low DBP should not discourage treatment of their elevated SBP to the recommended target, provided that treatment is well tolerated.

13. The need to do better on BP control. A key message in this guideline is the need to do better at improving BP control rates. Despite the overwhelming evidence of treatment benefit, on average, $<50 \%$ 
of patients with treated hypertension achieve a SBP target of $<140 \mathrm{mmHg}$. Physician inertia (inadequate up-titration of treatment, especially from monotherapy) and poor patient adherence to treatment (especially when based on multiple pills) are now recognised as the major factors contributing to poor BP control.

14. Start treatment in most patients with two drugs, not one. Monotherapy is usually inadequate therapy for most people with hypertension; this will be especially true now that the BP-treatment targets for many patients are lower than in previous guidelines. This guideline sets out to normalize the concept that initial therapy for the majority of patients with hypertension should be with a combination of two drugs, not a single drug. The only exception would be in a limited number of patients with a lower baseline BP close to their recommended target, who might achieve that target with a single drug, or in some frailer old or very old patients, in whom more gentle reduction of BP may be desirable. Evidence suggests that this approach will improve the speed, efficiency, and consistency of initial BP lowering and BP control, and is well tolerated by patients.

15. A single pill strategy to treat hypertension. Poor adherence to longer-term BP lowering medication is now recognised as a major factor contributing to poor BP control rates. Research has shown a direct correlation between the number of BP-lowering pills and poor adherence to medications. Moreover, SPC therapy has been shown to improve adherence to treatment. SPC therapy is now the preferred strategy for initial two-drug combination treatment of hypertension and for three-drug combination therapy when required. This will control the BP in most patients with a single pill and could transform BP control rates.

16. A simplified drug-treatment algorithm. We have simplified the treatment strategy so that patients with uncomplicated hypertension and many patients with a variety of comorbidities (e.g. HMOD, diabetes, PAD, or cerebrovascular disease) receive similar medication. We recommend a combination of an ACE inhibitor or ARB with a CCB or thiazide/thiazide-like diuretic as initial therapy for most patients. For those requiring three drugs, we recommend a combination of an ACE inhibitor or ARB with a CCB and a thiazide/thiazide-like diuretic. We recommend beta-blockers be used when there is a specific indication for their use (e.g. angina, post-myocardial infarction, HFrEF, or when heart-rate control is required).

17. Hypertension in women and in pregnancy. In women with hypertension who are planning pregnancy, ACE inhibitors or ARBs and diuretics should be avoided and the preferred medications to lower BP, if required, include alpha-methyl dopa, labetalol, or CCBs. The same drugs are suitable if BP lowering is required in pregnant women. ACE inhibitors or ARBs should not be used be used in pregnant women.

18. Is there a role for device-based therapy for the treatment of hypertension? A number of devicebased interventions have been developed and studied for the treatment of hypertension. To date, the results from these studies have not provided sufficient evidence to recommend their routine use. Consequently, the use of device-based therapies is not recommended for the treatment of hypertension, unless in the context of clinical studies and randomized controlled trials, until further evidence regarding their safety and efficacy becomes available.

19. Managing cardiovascular disease risk in hypertensive patients, beyond $\mathrm{BP}-$ statins. For hypertensive patients at moderate CVD risk or higher, or those with established CVD, BP lowering alone will not optimally reduce their risk. These patients would also benefit from statin therapy, which 
further reduces the risk of a myocardial infarction by approximately one-third and stroke by approximately one-quarter, even when BP is controlled. Similar benefits have been seen in hypertensive patients at the border between low and moderate risk. Thus, many more hypertensive patients would benefit from statin therapy than are currently receiving this treatment.

20. Managing cardiovascular disease risk in hypertensive patients, beyond BP - antiplatelet therapy. Antiplatelet therapy, especially low-dose aspirin, is recommended for secondary prevention in hypertensive patients, but is not recommended for primary prevention (i.e. in patients without CVD). 


\section{INTRODUCTION}

These 2018 European Society of Cardiology/European Society of Hypertension (ESC/ESH) guidelines for the management of arterial hypertension are designed for adults with hypertension, i.e. aged $\geq 18$ years. The purpose of the review and update of these guidelines was to evaluate and incorporate new evidence into the guideline recommendations. The specific aims of these guidelines were to produce pragmatic recommendations to improve the detection and treatment of hypertension, and to improve the poor rates of BP control by promoting simple and effective treatment strategies.

\subsection{Principles}

These fundamental principles are: (i) to base recommendations on properly conducted studies, identified from an extensive review of the literature; (ii) to give the highest priority to data from randomized, controlled trials (RCTs); (iii) to also consider well-conducted meta-analyses of RCTs as strong evidence. This contrasts with network meta-analyses, which we do not consider to have the same level of evidence because many of the comparisons are non-randomized; (iv) to recognise that RCTs cannot address many important questions related to the diagnosis, risk stratification, and treatment of hypertension, which can be addressed by observational or registry-based studies of appropriate scientific calibre; (v) to grade the level of scientific evidence and the strength of recommendations according to ESC recommendations; (vi) to recognise that opinions may differ on key recommendations, which are resolved by voting; and (vii) to recognise that there are circumstances in which there is inadequate or no evidence, but the question is important for clinical practice and cannot be ignored. In these circumstances, we resort to pragmatic expert opinion and endeavour to explain its rationale.

\subsection{What is new and what is changed in the 2018 ESC/ESH hypertension guidelines?}

Because of new evidence on several diagnostic and therapeutic aspects of hypertension, the present guidelines differ from the 2013 ones in several points indicated below (Figure 1): 
Figure 1: Changes in ESC/ESH recommendations between 2013 and 2018

\begin{tabular}{|c|c|}
\hline \multicolumn{2}{|l|}{ Changes in recommendations } \\
\hline 2013 & 2018 \\
\hline $\begin{array}{l}\text { Diagnosis } \\
\text { Office BP is recommended for screening and } \\
\text { diagnosis of hypertension. }\end{array}$ & $\begin{array}{l}\text { Diagnosis } \\
\text { It is recommended to base the diagnosis of } \\
\text { hypertension on: } \\
\text { - Repeated office BP measurements; or } \\
\text { - Out-of-office BP measurement with ABPM and/ } \\
\text { or HBPM if logistically and economically } \\
\text { feasible. }\end{array}$ \\
\hline $\begin{array}{l}\text { Treatment thresholds } \\
\text { High-normal BP (130-139/85-89 } \mathbf{~ m m H g ) : ~} \\
\text { Unless the necessary evidence is obtained it is } \\
\text { not recommended to initiate antihypertensive } \\
\text { drug therapy at high-normal BP. }\end{array}$ & $\begin{array}{l}\text { Treatment thresholds } \\
\text { High-normal BP (130-139/85-89 } \mathbf{~ m m H g ) : ~} \\
\text { Drug treatment may be considered when CV risk } \\
\text { is very high due to established CVD, especially } \\
\text { CAD. }\end{array}$ \\
\hline $\begin{array}{l}\text { Treatment thresholds } \\
\text { Treatment of low-risk grade } 1 \\
\text { hypertension: } \\
\text { Initiation of antihypertensive drug treatment } \\
\text { should also be considered in grade } 1 \\
\text { hypertensive patients at low to moderate risk, } \\
\text { when BP is within this range at several repeated } \\
\text { visits or elevated by ambulatory BP criteria, and } \\
\text { remains within this range despite a reasonable } \\
\text { period of time with lifestyle measures. }\end{array}$ & $\begin{array}{l}\text { Treatment thresholds } \\
\text { Treatment of low-risk grade } \mathbf{1} \text { hypertension: } \\
\text { In patients with grade } 1 \text { hypertension at low- } \\
\text { moderate risk and without evidence of HMOD, } \\
\text { BP-lowering drug treatment is recommended if } \\
\text { the patient remains hypertensive, after a period } \\
\text { of lifestyle intervention. }\end{array}$ \\
\hline $\begin{array}{l}\text { Treatment thresholds } \\
\text { Older patients } \\
\text { Antihypertensive drug treatment may be } \\
\text { considered in the elderly (at least when younger } \\
\text { than } 80 \text { years) when SBP is in the } 140-159 \\
\text { mmHg range, provided that antihypertensive } \\
\text { treatment is well tolerated. }\end{array}$ & $\begin{array}{l}\text { Treatment thresholds } \\
\text { Older patients } \\
\text { BP-lowering drug treatment and lifestyle } \\
\text { intervention is recommended in fit older patients } \\
\text { (> } 65 \text { years but not }>80 \text { years) when SBP is in } \\
\text { the grade } 1 \text { range } \\
(140-159 \mathrm{mmHg}), \text { provided that treatment is } \\
\text { well tolerated. }\end{array}$ \\
\hline
\end{tabular}

The codes used for the classes of recommendations and level of evidence are found in supplementary figure 1 . 


\begin{tabular}{|c|c|}
\hline 2013 & 2018 \\
\hline $\begin{array}{l}\text { BP treatment targets } \\
\text { A SBP goal of }<140 \mathrm{mmHg} \text { is recommended. }\end{array}$ & $\begin{array}{l}\text { BP treatment targets } \\
\text { - It is recommended that the first objective of } \\
\text { treatment should be to lower BP to }<140 / 90 \\
\mathrm{mmHg} \text { in all patients and provided that the } \\
\text { treatment is well tolerated, treated BP values } \\
\text { should be targeted to } 130 / 80 \mathrm{mmHg} \text { or lower, } \\
\text { in most patients. } \\
\text { - In patients < } 65 \text { years it is recommended that } \\
\text { SBP should be lowered to a BP range of } 120 \text { to } \\
<130 \mathrm{mmHg} \text { in most patients. }\end{array}$ \\
\hline $\begin{array}{l}\text { BP treatment targets in older patients } \\
\text { ( } 65-80 \text { years) } \\
\text { A SBP target between of } 140 \text { and } 150 \mathrm{mmHg} \text { is } \\
\text { recommended for older patients } \\
(65-80 \text { years). }\end{array}$ & $\begin{array}{l}\text { BP treatment targets in older patients } \\
\text { ( } 65-80 \text { years) } \\
\text { In older patients ( } \geq 65 \text { years), it is } \\
\text { recommended that SBP should be targeted to } \\
\text { a BP range of } 130 \text { to }<140 \mathrm{mmHg} \text {. }\end{array}$ \\
\hline $\begin{array}{l}\text { BP treatment targets in patients aged } \\
\text { over } 80 \text { years } \\
\text { A SBP target between } 140 \text { and } 150 \mathrm{mmHg} \\
\text { should be considered in people older than } 80 \\
\text { years, with an initial SBP } \geq 160 \mathrm{mmHg} \\
\text { provided that they are in good physical and } \\
\text { mental condition. }\end{array}$ & $\begin{array}{l}\text { BP treatment targets in patients aged } \\
\text { over } \mathbf{8 0} \text { years } \\
\text { A SBP target range of } 130 \text { to }<140 \mathrm{mmHg} \text { is } \\
\text { recommended for people older than } \\
80 \text { years, if tolerated. }\end{array}$ \\
\hline $\begin{array}{l}\text { DBP targets } \\
\text { A DBP target of }<90 \mathrm{mmHg} \text { is always } \\
\text { recommended, except in patients with diabetes, } \\
\text { in whom values }<85 \mathrm{mmHg} \text { are recommended. }\end{array}$ & $\begin{array}{l}\text { DBP targets } \\
\text { A DBP target of }<80 \mathrm{mmHg} \text { should be } \\
\text { considered for all hypertensive patients, } \\
\text { independent of the level of risk and } \\
\text { comorbidities. }\end{array}$ \\
\hline
\end{tabular}




\begin{tabular}{|c|c|}
\hline 2013 & 2018 \\
\hline $\begin{array}{l}\text { Initiation of drug treatment } \\
\text { Initiation of antihypertensive therapy with a } \\
\text { two-drug combination may be considered in } \\
\text { patients with markedly high baseline BP or at } \\
\text { high CV risk. }\end{array}$ & $\begin{array}{l}\text { Initiation of drug treatment } \\
\text { It is recommended to initiate an antihypertensive } \\
\text { treatment with a two-drug combination, } \\
\text { preferably in a SPC. The exceptions are frail } \\
\text { older patients and those at low risk and with } \\
\text { grade } 1 \text { hypertension (particularly if SBP is < } \\
150 \mathrm{mmHg} \text { ). }\end{array}$ \\
\hline $\begin{array}{l}\text { Resistant hypertension } \\
\text { Mineralocorticoid receptor antagonists, } \\
\text { amiloride, and the alpha- } 1 \text { blocker doxazosin } \\
\text { should be considered if no contraindication } \\
\text { exists. }\end{array}$ & $\begin{array}{l}\text { Resistant hypertension } \\
\text { Recommended treatment of resistant } \\
\text { hypertension is the addition of low-dose } \\
\text { spironolactone to existing treatment, or the } \\
\text { addition of further diuretic therapy if intolerant to } \\
\text { spironolactone, with either eplerenone, } \\
\text { amiloride, higher-dose thiazide/thiazide-like } \\
\text { diuretic or a loop diuretic, or the addition of } \\
\text { bisoprolol or doxazosin. }\end{array}$ \\
\hline $\begin{array}{l}\text { Device-based therapy for hypertension } \\
\text { In case of ineffectiveness of drug treatment, } \\
\text { invasive procedures such as renal denervation } \\
\text { and baroreceptor stimulation may be } \\
\text { considered. }\end{array}$ & $\begin{array}{l}\text { Device-based therapy for hypertension } \\
\text { Use of device-based therapies is not } \\
\text { recommended for the treatment of hypertension, } \\
\text { unless in the context of clinical studies and RCTs, } \\
\text { until further evidence regarding their safety and } \\
\text { efficacy becomes available. }\end{array}$ \\
\hline \multicolumn{2}{|l|}{ Recommendation Grading } \\
\hline Grade IIa & Grade IIb \\
\hline
\end{tabular}

$\mathrm{ABPM}=$ ambulatory blood pressure monitoring; $\mathrm{BP}=$ blood pressure; $\mathrm{CAD}=$ coronary artery disease; $\mathrm{CV}=$ cardiovascular; CVD = cardiovascular disease; $\mathrm{DBP}=$ diastolic blood pressure; HBPM = home blood pressure monitoring; $\mathrm{HMOD}=$ hypertension-mediated organ damage; $\mathrm{RCT}$ = randomized controlled trial; $\mathrm{SBP}=$ systolic blood pressure; SPC = single-pill combination.

\section{3 New concepts}

\section{BP measurement}

- Wider use of out-of-office BP measurement with ABPM and/or HBPM, especially HBPM, as an option to confirm the diagnosis of hypertension, detect white coat and masked hypertension and monitor BP control.

Less conservative treatment of BP in older and very old patients

- Lower BP thresholds and treatment targets for older patients - with emphasis on considerations of 
biological rather than chronological age (i.e. the importance of frailty, independence, and the tolerability of treatment).

- Recommendation that treatment should never be denied or withdrawn on the basis of age, provided that treatment is tolerated.

\section{A SPC treatment strategy to improve BP control}

- Preferred use of two-drug combination therapy for the initial treatment of most people with hypertension.

- A single-pill treatment strategy for hypertension with the preferred use SPC therapy for most patients.

- Simplified drug-treatment algorithms with the preferred use of an ACE inhibitor or ARB combined with a CCB or/and a thiazide/thiazide-like diuretic as the core treatment strategy for most patients, with beta-blockers used for specific indications.

New target ranges for $\mathrm{BP}$ in treated patients

- Target BP ranges for treated patients to better identify the recommended BP target and lower safety boundaries for treated BP, according to a patient's age and specific comorbidities.

\section{Detecting poor adherence to drug therapy}

- A strong emphasis on the importance of evaluating treatment adherence as a major cause of poor BP control.

A key role for nurses, pharmacists in the longer-term management of hypertension

- The important role of nurses and pharmacists in the education, support, and follow-up of treated hypertensive patients is emphasized as part of the overall strategy to improve BP control.

\section{Definitions and classifications}

The relationship between BP and CV and renal events is continuous, making the distinction between normotension and hypertension - based on cut-off BP values - somewhat arbitrary. "Hypertension" is defined as the level of BP at which the benefits of treatment (either with lifestyle interventions or drugs), unequivocally outweigh the risks of treatment, as documented by clinical trials. This evidence has been reviewed and provides the basis for the recommendation that the classification of BP and definition of hypertension remain unchanged from previous ESH/ESC guidelines (Figure 2) 
Figure 2: Classification of office BP and definitions of hypertension grades

\begin{tabular}{|c|c|c|c|}
\hline Categorya & Systolic (mmHg) & & Diastolic (mmHg) \\
\hline Optimal & $<120$ & and & $<80$ \\
\hline Normal & $120-129$ & and/or & $80-84$ \\
\hline High normal & $130-139$ & and/or & $85-89$ \\
\hline Grade 1 hypertension & $140-159$ & and/or & $90-99$ \\
\hline Grade 2 hypertension & $160-179$ & and/or & $100-109$ \\
\hline Grade 3 hypertension & $\geq 180$ & and/or & $\geq 110$ \\
\hline Isolated systolic hypertension ${ }^{b}$ & $\geq 140$ & and & $<90$ \\
\hline
\end{tabular}

a BP category is defined according to seated clinic BP and by the highest level of BP, whether systolic or diastolic. b Isolated systolic hypertension is graded 1, 2, or 3 according to SBP values in the ranges indicated.

\section{Diagnostic evaluation}

\subsection{Evaluation of the CV risk}

Quantification of total CV risk (i.e. the likelihood of a person developing a CV event over a defined period) is an important part of the risk-stratification process for patients with hypertension. Many CV risk-assessment systems are available and most project 10-year risk. Since 2003, the European guidelines on CVD prevention have recommended use of the Systematic COronary Risk Evaluation (SCORE) system (Figures 3 -5) because it is based on large, representative European cohort datasets (available at: http://www.escardio.org/Guidelines-\&-Education/Practice-tools/CVD-preventiontoolbox/SCORE-Risk-Charts). The SCORE system only estimates the risk of fatal CV events.

Figure 3: Evaluation of the CV risk: 10-year cardiovascular risk categories (SCORE)

\begin{tabular}{|c|c|}
\hline & $\begin{array}{l}\text { People with any of the following: } \\
\text { Documented CVD, either clinical or unequivocal on imaging. } \\
\text {-Clinical CVD includes; acute myocardial infarction, acute coronary syndrome, coronary or other arterial } \\
\text { revascularization, stroke, TIA, aortic aneurysm, PAD. }\end{array}$ \\
\hline Very high risk & $\begin{array}{l}\text { - Unequivocal documented CVD on imaging includes: significant plaque (i.e. } \geq 50 \% \text { stenosis) on } \\
\text { angiography or ultrasound. It does not include increase in carotid intima-media thickness. } \\
\text { Diabetes mellitus with target organ damage, e.g. proteinuria or a with a major risk factor such as } \\
\text { grade } 3 \text { hypertension or hypercholesterolaemia } \\
\text { Severe CKD (eGFR }<30 \mathrm{~mL} / \mathrm{min} / 1.73 \mathrm{~m}^{2} \text { ) } \\
\text { A calculated } 10 \text {-year SCORE of } \geq \mathbf{1 0 \%}\end{array}$ \\
\hline High risk & $\begin{array}{l}\text { People with any of the following: } \\
\text { Marked elevation of a single risk factor, particularly cholesterol }>8 \mathrm{mmol} / \mathrm{L}(>310 \mathrm{mg} / \mathrm{dL}) \\
\text { e.g. familial hypercholesterolaemia, grade } 3 \text { hypertension }(B P \geq 180 / 110 \mathrm{mmHg} \text { ) } \\
\text { Most other people with diabetes mellitus (except some young people with type } 1 \text { diabetes mellitus } \\
\text { and without major risk factors, that may be moderate risk) } \\
\text { Hypertensive LVH } \\
\text { Moderate CKD (eGFR } \mathbf{3 0}-\mathbf{5 9} \mathbf{~} \mathbf{m L} / \mathbf{m i n} / \mathbf{1 . 7 3} \mathbf{~ m}^{2} \text { ) } \\
\text { A calculated 10-year SCORE of } \mathbf{5 - 1 0 \%}\end{array}$ \\
\hline Moderate risk & $\begin{array}{l}\text { People with: } \\
\text { A calculated 10-year SCORE of } 1 \% \text { to }<5 \% \\
\text { Grade } 2 \text { hypertension } \\
\text { Many middle-aged people belong to this category }\end{array}$ \\
\hline Low risk & $\begin{array}{l}\text { People with: } \\
\text { A calculated 10-year SCORE of }<1 \%\end{array}$ \\
\hline
\end{tabular}


Figure 4: Risk modifiers increasing CV risk estimated by the SCORE system

\begin{tabular}{|l|}
\hline Social deprivation - the origin of many causes of CVD \\
\hline $\begin{array}{l}\text { Obesity (measured by BMI) and central obesity (measured by waist } \\
\text { circumference) }\end{array}$ \\
\hline Physical inactivity \\
\hline Psychosocial stress, including vital exhaustion \\
\hline $\begin{array}{l}\text { Family history of premature CVD (occurring at age }<55 \text { years in men and } \\
<60 \text { years in women) }\end{array}$ \\
\hline Autoimmune and other inflammatory disorders \\
\hline Major psychiatric disorders \\
\hline Treatment for infection with human immunodeficiency virus \\
\hline Atrial fibrillation \\
\hline LV hypertrophy \\
\hline CKD \\
\hline Obstructive sleep apnoea syndrome \\
\hline
\end{tabular}

Figure 5: Classification of hypertension stages according to BP levels, presence of risk factors, hypertension mediated organ damage (HMOD), or comorbidities.

\begin{tabular}{|c|c|c|c|c|c|}
\hline \multirow[b]{2}{*}{$\begin{array}{c}\text { Hypertension } \\
\text { disease staging }\end{array}$} & \multirow[b]{2}{*}{$\begin{array}{l}\text { Other risk factors, } \\
\text { HMOD, or disease }\end{array}$} & \multicolumn{4}{|c|}{ BP $(\mathrm{mmHg})$ grading } \\
\hline & & $\begin{array}{l}\text { High-normal } \\
\text { SBP } 130-139 \\
\text { DBP } 85-89\end{array}$ & $\begin{array}{l}\text { Grade } 1 \\
\text { SBP } 140-159 \\
\text { DBP } 90-99\end{array}$ & $\begin{array}{c}\text { Grade } 2 \\
\text { SBP } 160-179 \\
\text { DBP } 100-109\end{array}$ & $\begin{array}{c}\text { Grade } 3 \\
\mathrm{SBP} \geq 180 \\
\mathrm{DBP} \geq 110\end{array}$ \\
\hline \multirow{3}{*}{$\begin{array}{c}\text { Stage } 1 \\
\text { (uncomplicated) }\end{array}$} & No other risk factors & Low risk & Low risk & Moderate risk & High risk \\
\hline & 1 or 2 risk factors & Low risk & Moderate risk & $\begin{array}{c}\text { Moderate to } \\
\text { high risk }\end{array}$ & High risk \\
\hline & $\geq 3$ risk factors & $\begin{array}{l}\text { Low to } \\
\text { moderate risk }\end{array}$ & $\begin{array}{l}\text { Moderate to } \\
\text { high risk }\end{array}$ & High risk & High risk \\
\hline $\begin{array}{l}\text { Stage } 2 \\
\text { (asymptomatic } \\
\text { disease) }\end{array}$ & $\begin{array}{c}\text { HMOD, CKD grade } 3 \text {, or } \\
\text { diabetes mellitus } \\
\text { without organ damage }\end{array}$ & $\begin{array}{l}\text { Moderate to } \\
\text { high risk }\end{array}$ & High risk & High risk & $\begin{array}{l}\text { High to } \\
\text { very high risk }\end{array}$ \\
\hline $\begin{array}{l}\text { Stage } 3 \\
\text { (established } \\
\text { disease) }\end{array}$ & $\begin{array}{l}\text { Established CVD, } \\
\text { CKD grade } \geq 4 \text {, or } \\
\text { diabetes mellitus } \\
\text { with organ damage }\end{array}$ & Very high risk & Very high risk & Very high risk & Very high risk \\
\hline
\end{tabular}

$\mathrm{BP}=$ blood pressure $; \mathrm{CKD}=$ chronic kidney disease; $\mathrm{CV}$ = cardiovascular; $\mathrm{DBP}=$ diastolic blood pressure;

HMOD = hypertension-mediated organ damage; SBP = systolic blood pressure; SCORE = Systematic Coronary Risk

Evaluation. $\mathrm{CV}$ risk is illustrated for a middle-aged male. The CV risk does not necessarily correspond to the actual risk at different ages. The use of the SCORE system is recommended for formal estimation of CV risk for treatment decisions. 
These guidelines also support the use of out-of-office BP (i.e. HBPM and/or ABPM) (Figures 7-10) as an alternative strategy to repeated office BP measurements, to confirm the diagnosis of hypertension, when these measurements are logistically and economically feasible. This approach can provide important supplementary clinical information, for example, detecting white-coat hypertension, which should be suspected, especially in people with grade 1 hypertension on office BP measurement and in whom there is no evidence of HMOD or CVD. A particular challenge is the detection of masked hypertension. Masked hypertension is more likely in people with a BP in the high-normal range in whom out-of-office BP should be considered to exclude masked hypertension. Out-of-office BP measurements are also indicated in other specific circumstances (Figures 7-9).

Figure 7: Definitions of hypertension according to office, ambulatory, and home BP levels

\begin{tabular}{|l|c|c|c|}
\hline Category & Systolic $\mathbf{( m m H g )}$ & & Diastolic $\mathbf{( m m H g )}$ \\
\hline Office BPa & $\geq 140$ & and/or & $\geq 90$ \\
\hline Ambulatory BP & & & \\
\hline Daytime (or awake) mean & $\geq 135$ & and/or & $\geq 85$ \\
\hline Night-time (or asleep) mean & $\geq 120$ & and/or & $\geq 70$ \\
\hline 24-h mean & $\geq 130$ & and/or & $\geq 80$ \\
\hline Home BP mean & $\geq 135$ & and/or & $\geq 85$ \\
\hline
\end{tabular}

$\mathrm{BP}$, blood pressure; ${ }^{\text {Refers to }}$ conventional office BP rather than unattended office BP.

Figure 8: Advantages and disadvantages of ambulatory blood pressure monitoring and home blood pressure monitoring

\begin{tabular}{|c|c|}
\hline ABPM & HВРM \\
\hline Advantages & Advantages \\
\hline $\begin{array}{l}\text { - Can identify white-coat and masked } \\
\text { hypertension }\end{array}$ & $\begin{array}{l}\text { - Can identify white-coat and masked } \\
\text { hypertension }\end{array}$ \\
\hline - Stronger prognostic evidence & - Cheap and widely available \\
\hline - Night-time readings & - Measurement in a home setting, which may \\
\hline - Measurement in real-life settings & \\
\hline - Additional prognostic BP phenotypes & - Patient engagement in BP measurement \\
\hline $\begin{array}{l}\text { - Abundant information from a single } \\
\text { measurement session, including short- } \\
\text { term BP variability }\end{array}$ & $\begin{array}{l}\text { - Easily repeated and used over longer } \\
\text { periods to assess day-to-day BP variability }\end{array}$ \\
\hline Disadvantages & Disadvantages \\
\hline - Expensive and sometimes limited & - Only static BP is available \\
\hline availability & - Potential for measurement error \\
\hline - Can be uncomfortable & - No nocturnal readings \\
\hline
\end{tabular}

ABPM, ambulatory blood pressure monitoring; BP, blood pressure; HBPM, home blood pressure monitoring. aTechniques are being developed to enable nocturnal BP measurement with home BP devices. 
Conditions in which white-coat hypertension is more common, e.g.

- Grade I hypertension on office BP measurement

- Marked office BP elevation without HMOD

Conditions in which masked hypertension is more common, e.g.

- High-normal office BP

- Normal office BP in individuals with HMOD or at high total CV risk

Postural and post-prandial hypotension in untreated and treated patients

Evaluation of resistant hypertension

Evaluation of BP control, especially in treated higher-risk patients

Exaggerated $\mathrm{BP}$ response to exercise

When there is considerable variability in the office BP

Evaluating symptoms consistent with hypotension during treatment

Specific indications for ABPM rather than HBPM:

- Assessment of nocturnal BP values and dipping status (e.g. suspicion of nocturnal hypertension, such as in sleep apnoea, CKD, diabetes, endocrine hypertension, or autonomic dysfunction)

All adults should have their BP recorded in their medical record and be aware of their BP, and further screening should be undertaken at regular intervals with the frequency dependent on the BP level as illustrated in Figure 10.

Figure 10: Screening for hypertension

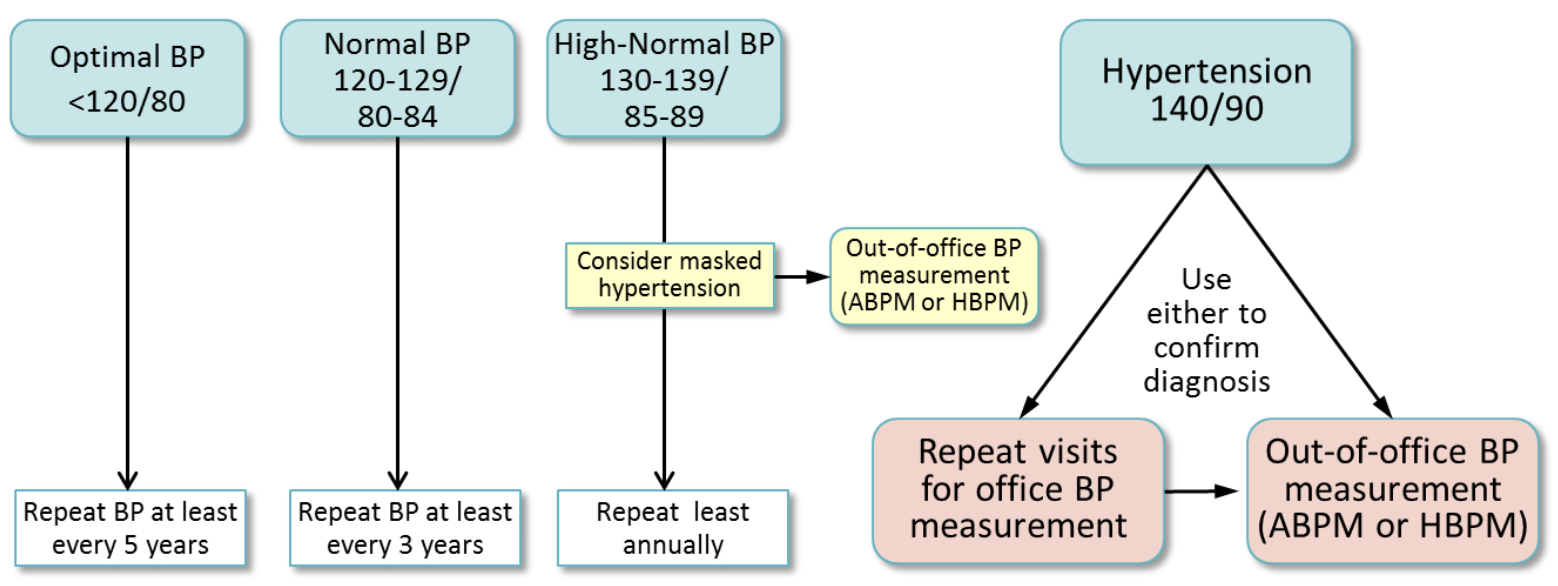

$A B P M=$ ambulatory blood pressure monitoring; $B P=$ blood pressure; $H B P M=$ home blood pressure monitoring. After detecting a specific BP category on screening, either confirm BP elevation with repeated office BP measurements on repeat visits, or arrange use of out-of-office BP to confirm the diagnosis of hypertension 


\subsection{Clinical evaluation}

The information to be obtained at the time of the first diagnosis of hypertension is indicated in the Figures 11-14.

Figure 11: Key information to be collected in personal and family medical history (1)

\begin{tabular}{|l|}
\hline Risk factors \\
\hline Family and personal history of hypertension, CVD, stroke, or renal disease \\
\hline Family and personal history of associated risk factors (e.g. familial hypercholesterolaemia) \\
\hline Smoking history \\
\hline Dietary history and salt intake \\
\hline Alcohol consumption \\
\hline Lack of physical exercise/sedentary lifestyle \\
\hline History of erectile dysfunction \\
\hline Sleep history, snoring, sleep apnoea (information also from partner) \\
\hline Previous hypertension in pregnancy/pre-eclampsia \\
\hline History and symptoms of HMOD, CVD, stroke, and renal disease \\
\hline $\begin{array}{l}\text { Brain and eyes: headache, vertigo, syncope, impaired vision, TIA, sensory or motor deficit, stroke, } \\
\text { carotid revascularization, cognitive impairment, or dementia (in the elderly) }\end{array}$ \\
\hline $\begin{array}{l}\text { Heart: chest pain, shortness of breath, oedema, myocardial infarction, coronary revascularization, } \\
\text { syncope, history of palpitations, arrhythmias (especially AF), heart failure }\end{array}$ \\
\hline Kidney: thirst, polyuria, nocturia, haematuria, urinary tract infections \\
\hline $\begin{array}{l}\text { Peripheral arteries: cold extremities, intermittent claudication, pain-free walking distance, pain at rest, } \\
\text { peripheral revascularization }\end{array}$ \\
\hline Patient or family history of CKD (e.g. polycystic kidney disease) \\
\hline
\end{tabular}

Figure 12: Key information to be collected in personal and family medical history (2)

\begin{tabular}{|l|}
\hline History of possible secondary hypertension \\
\hline $\begin{array}{l}\text { Young onset of grade } 2 \text { or } 3 \text { hypertension (< } 40 \text { years), or sudden development of hypertension or } \\
\text { rapidly worsening BP in older patients }\end{array}$ \\
\hline History of renal/urinary tract disease \\
\hline $\begin{array}{l}\text { Recreational drug/substance abuse/concurrent therapies: corticosteroids, nasal vasoconstrictor, } \\
\text { chemotherapy, yohimbine, liquorice }\end{array}$ \\
\hline Repetitive episodes of sweating, headache, anxiety, palpitations, suggestive of pheochromocytoma \\
\hline $\begin{array}{l}\text { History of spontaneous or diuretic-provoked hypokalaemia, episodes of muscle weakness, and tetany } \\
\text { (hyperaldosteronism) }\end{array}$ \\
\hline Symptoms suggestive of thyroid disease or hyperparathyroidism \\
\hline History of or current pregnancy and oral contraceptive use \\
\hline History of sleep apnoea \\
\hline Hypertension treatment \\
\hline $\begin{array}{l}\text { Current/past antihypertensive medication including effectiveness and intolerance to previous } \\
\text { medications }\end{array}$ \\
\hline Adherence to therapy \\
\hline
\end{tabular}


Figure 13: Routine work-up for evaluation of hypertensive patients

\begin{tabular}{|l|}
\hline Routine laboratory tests \\
\hline Haemoglobin and/or haematocrit \\
\hline Fasting blood glucose and glycated $\mathrm{HbA}_{1 \mathrm{c}}$ \\
\hline $\begin{array}{l}\text { Blood lipids: total cholesterol, low-density lipoprotein cholesterol, } \\
\text { high-density lipoprotein cholesterol }\end{array}$ \\
\hline Blood triglycerides \\
\hline Blood potassium and sodium \\
\hline Blood uric acid \\
\hline Blood creatinine and eGFR \\
\hline Blood liver function tests \\
\hline $\begin{array}{l}\text { Urine analysis: microscopic examination; urinary protein by dipstick test or, } \\
\text { ideally, albumin:creatinine ratio }\end{array}$ \\
\hline 12 -lead ECG \\
\hline
\end{tabular}

HB A $A_{1 c}$ : Glycosylated hemoglobin; eGFR: estimated glomerular filtration rate; ECG: electrocardiogram

\section{Figure 14: Assessments of hypertension mediated organ damage (HMOD)}

\begin{tabular}{|c|c|}
\hline Basic screening tests for HMOD & Indication and interpretation \\
\hline 12-lead ECG & $\begin{array}{l}\text { Screen for LVH and other possible cardiac abnormalities and to document heart rate and } \\
\text { cardiac rhythm }\end{array}$ \\
\hline Urine albumin:creatinine ratio & To detect elevations in albumin excretion indicative of possible renal disease \\
\hline Blood creatinine and eGFR & To detect possible renal disease \\
\hline Fundoscopy & To detect hypertensive retinopathy, especially in patients with grade 2 or 3 hypertension \\
\hline \multicolumn{2}{|l|}{ More detailed screening for HMOD } \\
\hline Echocardiography & $\begin{array}{l}\text { To evaluate cardiac structure and function, when this information will influence treatment } \\
\text { decisions }\end{array}$ \\
\hline Carotid ultrasound & $\begin{array}{l}\text { To determine the presence of carotid plaque or stenosis, particularly in patients with } \\
\text { cerebrovascular disease or vascular disease elsewhere }\end{array}$ \\
\hline $\begin{array}{l}\text { Abdominal ultrasound and Doppler } \\
\text { studies }\end{array}$ & $\begin{array}{l}\text { To evaluate renal size and structure (e.g. scarring) and exclude renal tract obstruction as } \\
\text { possible underlying causes of CKD and hypertension } \\
\text { Evaluate abdominal aorta for evidence of aneurysmal dilatation and vascular disease. } \\
\text { Examine adrenal glands for evidence of adenoma or phaeochromocytoma (CT or MRI preferred } \\
\text { for detailed examination) } \\
\text { Renal artery Doppler studies to screen for the presence of renovascular disease, especially in } \\
\text { the presence of asymmetric renal size }\end{array}$ \\
\hline PWV & An index of aortic stiffness and underlying arteriosclerosis \\
\hline ABI & Screen for evidence of PAD \\
\hline Cognitive function testing & To evaluate cognition in patients with symptoms suggestive of cognitive impairment \\
\hline Brain imaging & $\begin{array}{l}\text { To evaluate the presence of ischaemic or haemorrhagic brain injury, especially in patients with } \\
\text { a history of cerebrovascular disease or cognitive decline }\end{array}$ \\
\hline
\end{tabular}

ECG: electrocardiogram; LVH: left ventricular hypertrophy; eGFR: estimated glomerular filtration rate; PWV: pulse wave velocity, ABI: ankle brachial index; PAD: peripheral artery disease. 


\section{Treatment of hypertension}

The routine treatment of hypertension involves lifestyle interventions for all patients (including those with high normal BP) and drug therapy for most patients.

All guidelines agree that patients with grade 2 or 3 hypertension should receive antihypertensive drug treatment alongside lifestyle interventions. Guidelines are also consistent in recommending that patients with grade 1 hypertension and high CV risk or HMOD should be treated with BP-lowering drugs. There has been less consistency about whether BP-lowering drugs should be offered to patients with grade 1 hypertension and low-to-moderate $\mathrm{CV}$ risk or grade 1 hypertension in older patients (> 60 years), or the need for BP-lowering drug treatment in patients with high-normal BP levels. This uncertainty relates to the fact that low-risk patients with high-normal BP or grade 1 hypertension have rarely been included in RCTs, and that in older patients, RCTs have invariably recruited patients with at least grade 2 hypertension.

\subsection{Drug treatment strategy and blood pressure targets (Figure 15-20)}

Figure 15. Initiation of BP-lowering treatment (lifestyle changes and medication at different initial office BP levels

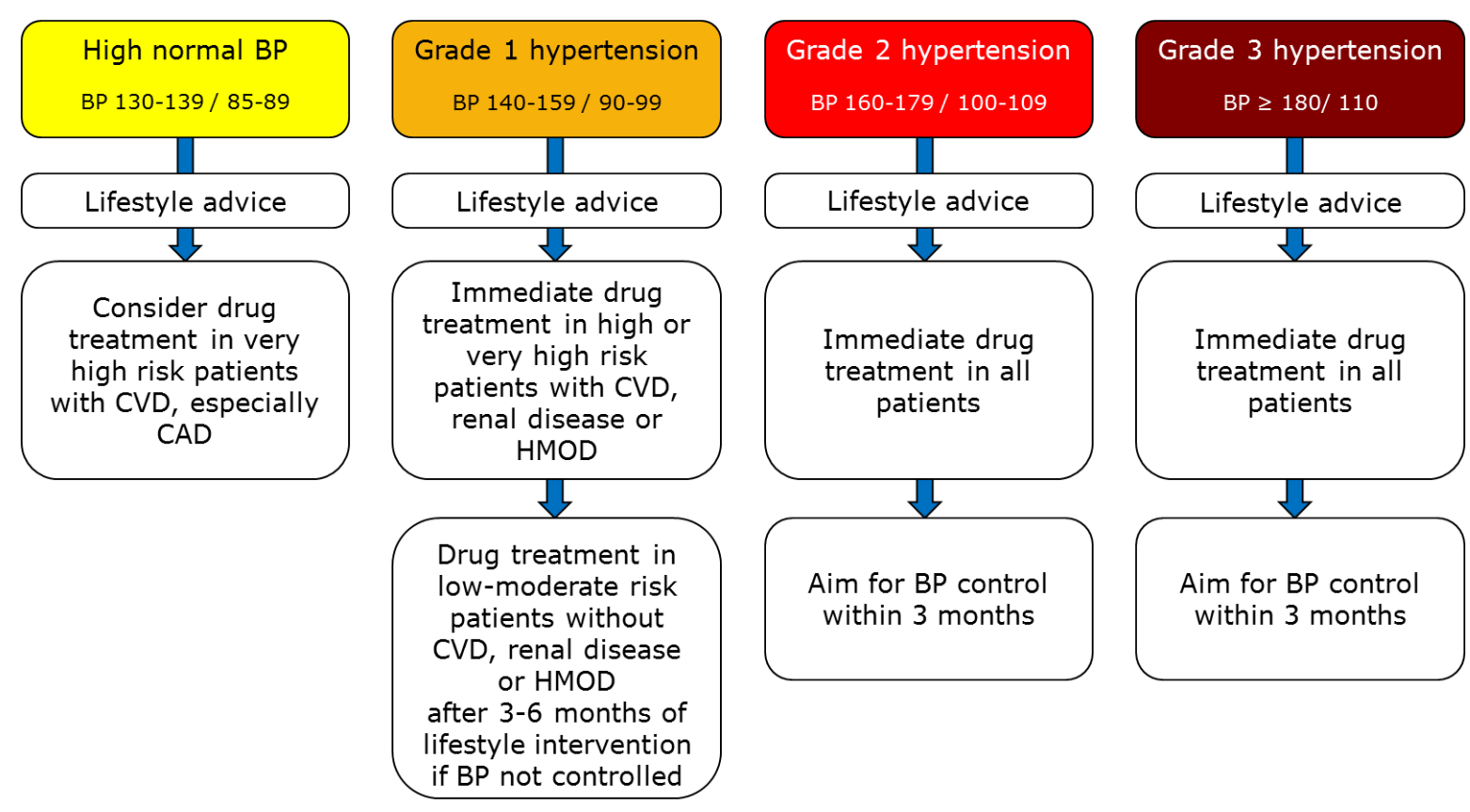


Figure 16: Summary of office BP thresholds for treatment

\begin{tabular}{|l|c|c|c|c|c|c|}
\hline \multirow{2}{*}{ Age group } & \multicolumn{5}{|c|}{ Office SBP treatment threshold (mmHg) } & $\begin{array}{c}\text { Diastolic } \\
\text { treatment } \\
\text { threshold } \\
\text { (mmHg) }\end{array}$ \\
\cline { 2 - 7 } & Hypertension & + Diabetes & + CKD & + CAD & + Stroke/TIA & $\geq 90$ \\
\hline $18-65$ years & $\geq 140$ & $\geq 140$ & $\geq 140$ & $\geq 140$ & $\geq 140$ & $\geq 90$ \\
\hline $65-79$ years & $\geq 140$ & $\geq 140$ & $\geq 140$ & $\geq 140$ & $\geq 140$ & $\geq 90$ \\
\hline$\geq 80$ years & $\geq 160$ & $\geq 160$ & $\geq 160$ & $\geq 160$ & $\geq 160$ & $\geq 90$ \\
\hline $\begin{array}{l}\text { Diastolic } \\
\text { treatment } \\
\text { threshold } \\
\text { (mmHg) }\end{array}$ & $\geq 90$ & $\geq 90$ & $\geq 90$ & $\geq 90$ & $\geq$ & \\
\hline
\end{tabular}

CAD: coronary artery disease; CKD: chronic kidney disease; SBP: systolic blood pressure; TIA: transient ischaemic attack.

\section{Figure 17: Office BP treatment targets in hypertensive: recommendations}

The level to which BP should be lowered with drug treatment will depend on the patients' age, comorbidities and tolerability of treatment. Corresponding BP targets for home and ambulatory BP are less well established but an office BP $<130 \mathrm{mmHg}$ probably corresponds to a $24 \mathrm{hr}$ ABPM systolic BP of $<125 \mathrm{mmHg}$ and a home average systolic $\mathrm{BP}$ of $<130 \mathrm{mmHg}$.

\section{Recommendations}

It is recommended that the first objective of treatment should be to lower BP to $<140 / 90$ $\mathrm{mmHg}$ in all patients, and provided that the treatment is well tolerated, treated BP values should be targeted to $130 / 80 \mathrm{mmHg}$ or lower, in most patients.

In patients $<65$ years receiving BP-lowering drugs, it is recommended that SBP should be lowered to a BP range of 120 to $<130 \mathrm{mmHg}$ in most patients.

In older patients (aged $\geq 65$ years) receiving BP-lowering drugs:

- It is recommended that SBP should be targeted to a BP range of 130 to $<140 \mathrm{mmHg}$.

- Close monitoring of adverse effects is recommended.

- These BP targets are recommended for patients at any level of CV risk and in patients with and without established CVD.

In patients with diabetes receiving BP-lowering drugs:

- An SBP target range of $120-130 \mathrm{mmHg}$ should be considered.

- In older patients (aged $\geq 65$ years) an SBP target range of 130 to $<140 \mathrm{mmHg}$ is recommended.

A DBP target of $<80 \mathrm{mmHg}$ should be considered for all hypertensive patients, independent of the level of risk and comorbidities. 


\section{Figure 18: Life style changes}

\begin{tabular}{|c|}
\hline Recommendations \\
\hline Salt restriction to $<5 \mathrm{~g}$ per day is recommended. \\
\hline $\begin{array}{l}\text { It is recommended to restrict alcohol consumption to: } \\
\text { - Less than } 14 \text { units per week for men. } \\
\text { - Less than } 8 \text { units per week for women. }\end{array}$ \\
\hline It is recommended to avoid binge drinking. \\
\hline $\begin{array}{l}\text { Increased consumption of vegetables, fresh fruits, fish, nuts, unsaturated fatty acids } \\
\text { (olive oil), low consumption of red meat, and consumption of low-fat dairy products } \\
\text { are recommended. }\end{array}$ \\
\hline $\begin{array}{l}\text { Body-weight control is indicated to avoid obesity (BMI }>30 \mathrm{~kg} / \mathrm{m}^{2} \text { or WC }>102 \mathrm{~cm} \\
\text { in men and }>88 \mathrm{~cm} \text { in women) and aim at a healthy BMI (about } 20-25 \mathrm{~kg} / \mathrm{m}^{2} \text { ) and } \\
\text { WC values ( }<94 \mathrm{~cm} \text { in men and }<80 \mathrm{~cm} \text { in women) to reduce BP and CV risk. }\end{array}$ \\
\hline $\begin{array}{l}\text { Regular aerobic exercise (e.g. at least } 30 \text { min of moderate dynamic exercise on } \\
5-7 \text { days per week) is recommended. }\end{array}$ \\
\hline $\begin{array}{l}\text { Smoking cessation and supportive care and referral to smoking cessation programs } \\
\text { are recommended. }\end{array}$ \\
\hline
\end{tabular}

\section{Figure 19: Core drug-treatment strategy for uncomplicated hypertension}

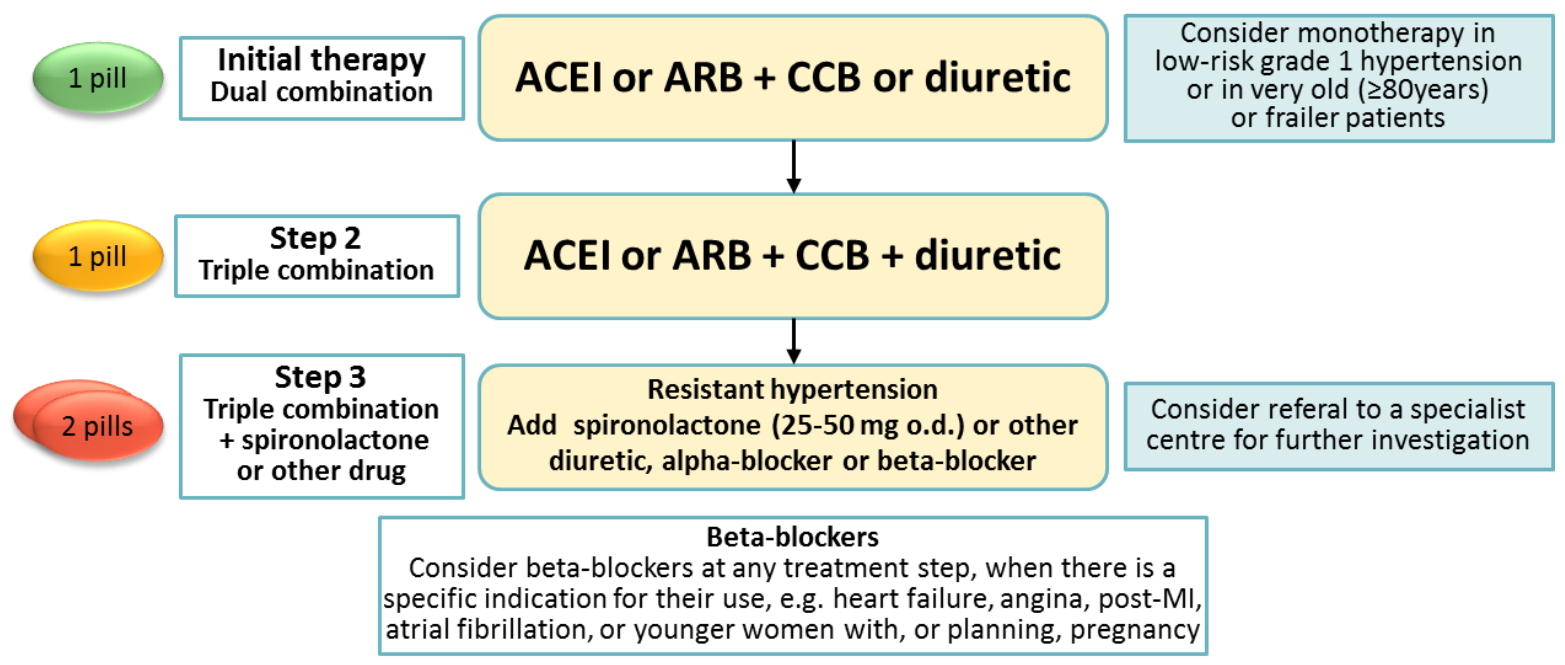

The core algorithm is also appropriate for most patients with HMOD, cerebrovascular disease, diabetes, or peripheral artery disease. 
Figure 20: Compelling and possible contraindications to the use of specific antihypertensive drugs

\begin{tabular}{|c|c|c|}
\hline \multirow{2}{*}{ Drug } & \multicolumn{2}{|l|}{ Contraindications } \\
\hline & Compelling & Possible \\
\hline $\begin{array}{l}\text { Diuretics } \\
\text { (thiazides/thiazide- } \\
\text { type, e.g. } \\
\text { chlorthalidone and } \\
\text { indapamide) } \\
\end{array}$ & - $\quad$ Gout & $\begin{array}{ll} & \text { Metabolic syndrome } \\
\text { - } & \text { Glucose intolerance } \\
\text { - } & \text { Hypercalcemia } \\
& \text { Hypokalemia } \\
\end{array}$ \\
\hline Beta-blockers & 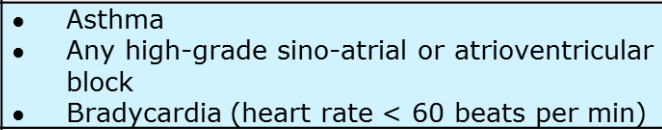 & $\begin{array}{ll} & \text { Metabolic syndrome } \\
\text { - } & \text { Glucose intolerance } \\
& \text { Athletes and physically active } \\
& \text { patients } \\
\end{array}$ \\
\hline $\begin{array}{l}\text { Calcium antagonists } \\
\text { (dihydropyridines) }\end{array}$ & & $\begin{array}{ll}\text { - } & \text { Tachyarrhythmia } \\
\text { - } & \text { Heart failure (HFrEF, class III or IV) } \\
\end{array}$ \\
\hline $\begin{array}{l}\text { Calcium antagonists } \\
\text { (verapamil, diltiazem) }\end{array}$ & $\begin{array}{ll} & \text { Any high-grade sino-atrial or AV block } \\
\text { - } & \text { Severe LV dysfunction (LV EF < 40\%) } \\
\text { - } & \text { Bradycardia (heart rate }<60 \text { beats per min) } \\
\end{array}$ & - Constipation \\
\hline ACE inhibitors & $\begin{array}{l}\text { - } \quad \text { Pregnancy } \\
\text { - } \quad \text { Previous angioneurotic oedema } \\
\text { - } \quad \text { Hyperkalemia (potassium > } 5.5 \mathrm{mmol} / \mathrm{L} \text { ) } \\
\text { Bilateral renal artery stenosis }\end{array}$ & $\begin{array}{l}\text { Women of child-bearing potential } \\
\text { without reliable contraception }\end{array}$ \\
\hline ARBs & $\begin{array}{ll} & \text { Pregnancy } \\
\text { - } & \text { Hyperkalemia (potassium > } 5.5 \mathrm{mmol} / \mathrm{L} \text { ) } \\
\text { - } & \text { Bilateral renal artery stenosis } \\
\end{array}$ & $\begin{array}{l}\text { - Women of child-bearing potential } \\
\text { without reliable contraception }\end{array}$ \\
\hline
\end{tabular}

4.2. Drug treatment strategy for specific clinical situations: coronary heart disease, chronic kidney disease, heart failure, atrial fibrillation (Figures 21-25)

Figure 21: Drug-treatment strategy for hypertension and CAD

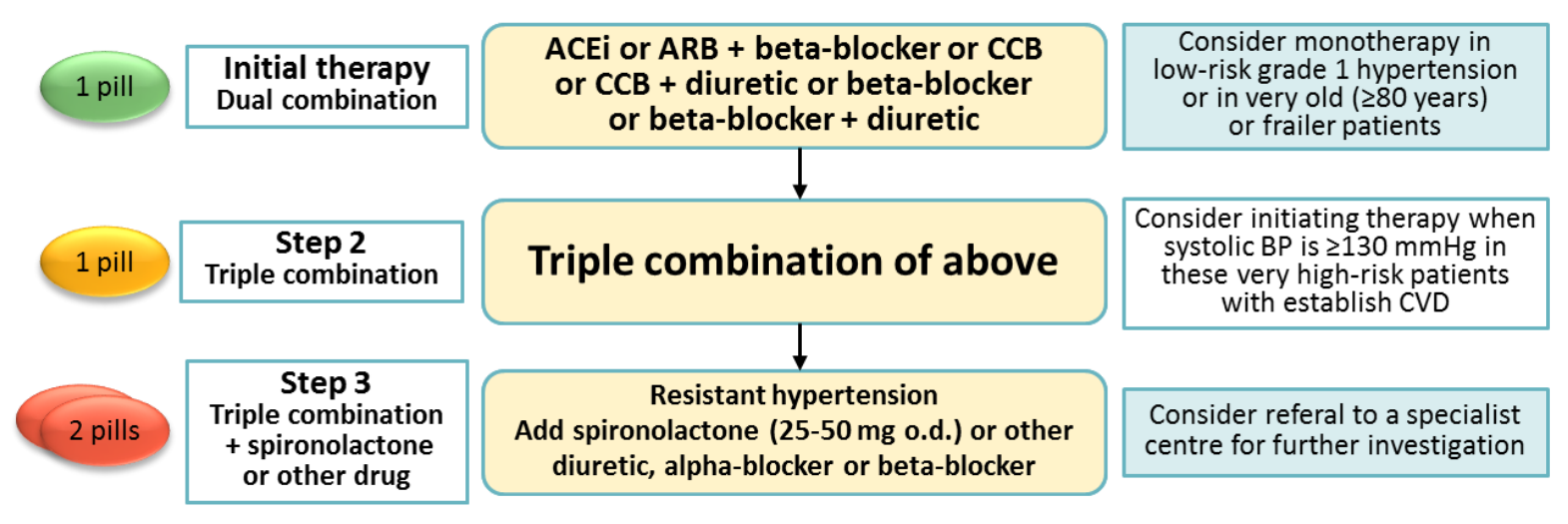


Figure 22: Drug-treatment strategy for chronic kidney disease (CKD)

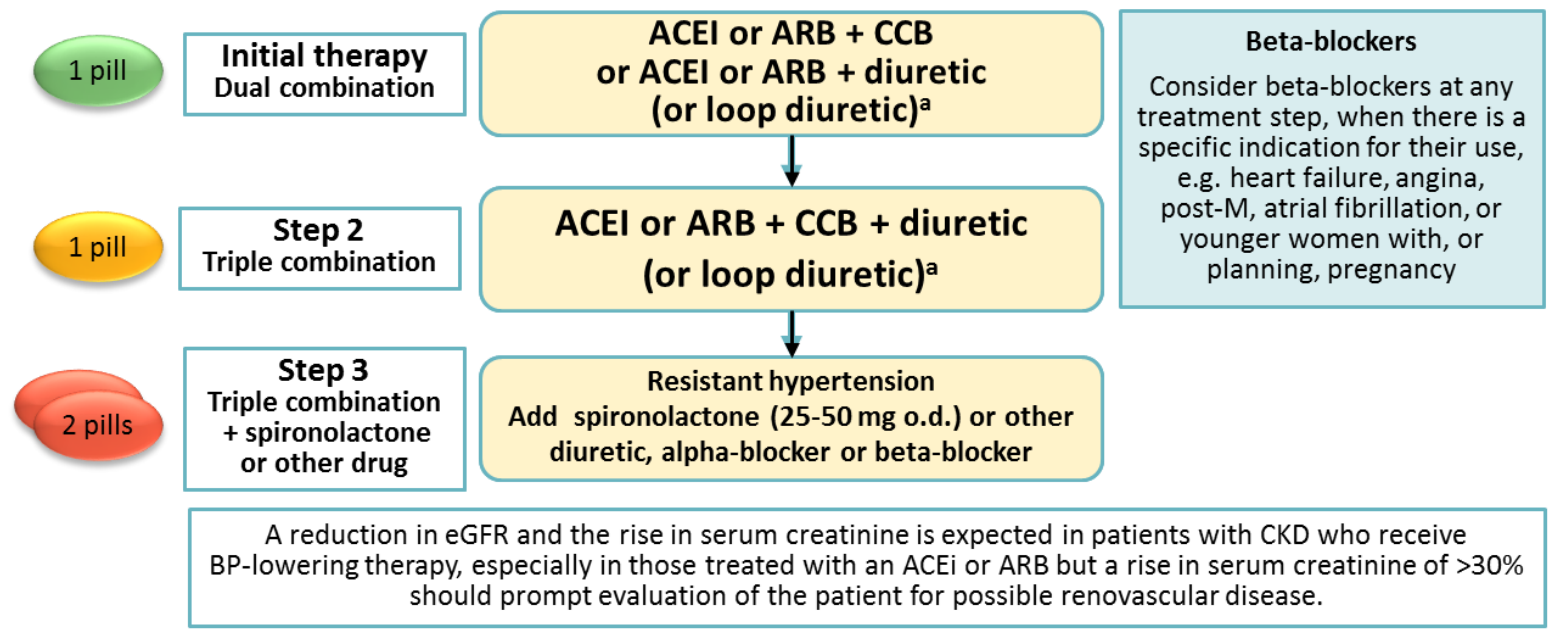

${ }^{\mathrm{a}}$ Use loop diuretics when eGFR is $<30 \mathrm{~mL} / \mathrm{min} / 1.72 \mathrm{~m} 2$, because thiazide/thiazide-like diuretics are much less effective/ineffective when eGFR is reduced to this level.

Figure 23: Drug-treatment strategy for hypertension and heart failure with reduced ejection fraction (HRrEF)
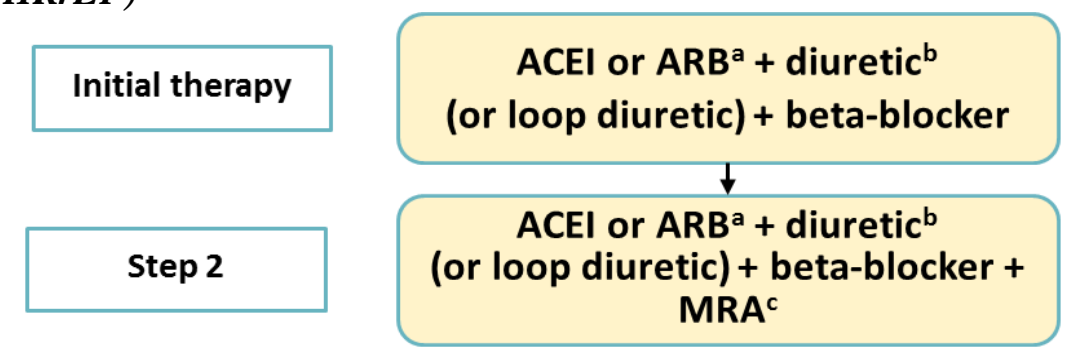

When antihypertensive therapy is not require in HFrEF, treatment should be prescribed accoring to the ESC Heart Failure Guidelines

\footnotetext{
${ }^{\mathrm{a}}$ Consider an angiotensin receptor/neprilysin inhibitor instead of ACEi or ARB per ESC Heart Failure Guidelines.

${ }^{b}$ Diuretic refers to thiazide/thiazide-like diuretic. Consider a loop diuretic as an alternative in patients with oedema.

CMRA (spironolactone or eplerenone).
}

Figure 24: Drug-treatment strategy for hypertension and atrial fibrillation (AF)

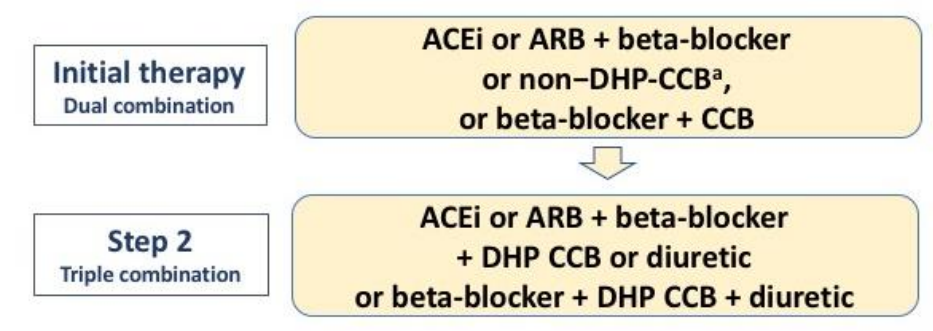

Add oral anticoagulation when indicated according to the $\mathrm{CHA}_{2} \mathrm{DS}_{2}$-VASc score, unless contraindicated.

Routine combination of beta-blockers with non-dihydropyridine CCBs (e.g. verapamil or diltiazem) is not recommended due to a potential marked reduction in heart rate. 
Figure 25: Treatment targets in special conditions

\begin{tabular}{|c|c|c|c|c|c|c|}
\hline \multirow{2}{*}{ Age group } & \multicolumn{5}{|c|}{ Office SBP treatment target ranges $(\mathrm{mmHg})$} & \multirow{2}{*}{$\begin{array}{c}\text { Diastolic } \\
\text { treatment } \\
\text { target } \\
\text { range } \\
(\mathrm{mmHg})\end{array}$} \\
\hline & Hypertension & + Diabetes & $+\mathrm{CKD}$ & $+C A D$ & + Stroke/TIA & \\
\hline $18-65$ years & $\begin{array}{c}\text { Target to } \mathbf{1 3 0} \\
\text { or lower if } \\
\text { tolerated } \\
\text { Not }<120\end{array}$ & $\begin{array}{c}\text { Target to } \mathbf{1 3 0} \\
\text { or lower if } \\
\text { tolerated } \\
\text { Not }<120\end{array}$ & $\begin{array}{c}\text { Target to } \\
<\mathbf{1 4 0} \text { to } 130 \\
\text { if tolerated }\end{array}$ & $\begin{array}{c}\text { Target to } \mathbf{1 3 0} \\
\text { or lower if } \\
\text { tolerated } \\
\text { Not }<120\end{array}$ & $\begin{array}{c}\text { Target to } \mathbf{1 3 0} \\
\text { or lower if } \\
\text { tolerated } \\
\text { Not }<120\end{array}$ & $<80$ to 70 \\
\hline $65-79$ years & $\begin{array}{c}\text { Target to } \\
<\mathbf{1 4 0} \text { to } \mathbf{1 3 0} \\
\text { if tolerated }\end{array}$ & $\begin{array}{c}\text { Target to } \\
<\mathbf{1 4 0} \text { to } \mathbf{1 3 0} \\
\text { if tolerated }\end{array}$ & $\begin{array}{c}\text { Target to } \\
<\mathbf{1 4 0} \text { to } \mathbf{1 3 0} \\
\text { if tolerated }\end{array}$ & $\begin{array}{c}\text { Target to } \\
<\mathbf{1 4 0} \text { to } \mathbf{1 3 0} \\
\text { if tolerated }\end{array}$ & $\begin{array}{c}\text { Target to } \\
<\mathbf{1 4 0} \text { to } 130 \\
\text { if tolerated }\end{array}$ & $<80$ to 70 \\
\hline$\geq 80$ years & $\begin{array}{c}\text { Target to } \\
<\mathbf{1 4 0} \text { to } \mathbf{1 3 0} \\
\text { if tolerated }\end{array}$ & $\begin{array}{c}\text { Target to } \\
<\mathbf{1 4 0} \text { to } \mathbf{1 3 0} \\
\text { if tolerated }\end{array}$ & $\begin{array}{c}\text { Target to } \\
<\mathbf{1 4 0} \text { to } \mathbf{1 3 0} \\
\text { if tolerated }\end{array}$ & $\begin{array}{c}\text { Target to } \\
<\mathbf{1 4 0} \text { to } \mathbf{1 3 0} \\
\text { if tolerated }\end{array}$ & $\begin{array}{c}\text { Target to } \\
<\mathbf{1 4 0} \text { to } \mathbf{1 3 0} \\
\text { if tolerated }\end{array}$ & $<80$ to 70 \\
\hline $\begin{array}{l}\text { Diastolic } \\
\text { treatment } \\
\text { target range } \\
(\mathbf{m m H g})\end{array}$ & $<80$ to 70 & $<80$ to 70 & $<80$ to 70 & $<80$ to 70 & $<80$ to 70 & \\
\hline
\end{tabular}

CAD: coronary artery disease; CKD: chronic kidney disease; SBP: systolic blood pressure; TIA: transient ischemic attack.

\subsection{Device-based therapy for hypertension}

The actual recommendation is the following: "Use of device-based therapies is not recommended for the routine treatment of hypertension, unless in the context of clinical studies and RCTs, until further evidence regarding their safety and efficacy becomes available".

\subsection{Resistant hypertension (Figures 26 and 27)}

Hypertension is defined as resistant to treatment when the recommended treatment strategy fails to lower office SBP and DBP values to below $140 \mathrm{mmHg}$ and/or $90 \mathrm{mmHg}$, respectively, and the inadequate control of BP is confirmed by ABPM or HBPM, in patients whose adherence to therapy has been confirmed. The recommended treatment strategy should include appropriate lifestyle measures and treatment with optimal or best-tolerated doses of three or more drugs that should include a diuretic and typically an ACE inhibitor or ARB, and a CCB. 
Figure 26: Resistant hypertension characteristics, secondary causes, and contributing factors

\begin{tabular}{|c|c|c|}
\hline $\begin{array}{l}\text { Characteristics of patients with resistant } \\
\text { hypertension }\end{array}$ & $\begin{array}{l}\text { Causes of secondary resistant } \\
\text { hypertension }\end{array}$ & $\begin{array}{l}\text { Drugs and substances that may cause raised } \\
\text { BP }\end{array}$ \\
\hline $\begin{array}{l}\text { Demographics } \\
\text { - Older age (especially > } 75 \text { years) } \\
\text { - Obesity } \\
\text {-More common in black people } \\
\text { - Excess dietary sodium intake } \\
\text { - High baseline BP and chronicity of } \\
\text { uncontrolled hypertension }\end{array}$ & $\begin{array}{l}\text { More common causes } \\
\text {-Primary hyperaldosteronism } \\
\text {-Atherosclerotic renovascular disease } \\
\text {-Sleep apnoea } \\
\text {-CKD }\end{array}$ & $\begin{array}{l}\text { Prescribed drugs } \\
\text {-Oral contraceptives } \\
\text {-Sympathomimetic agents (e.g. decongestants in } \\
\text { proprietary cold remedies) } \\
\text {-Non-steroidal anti-inflammatory drugs } \\
\text {-Cyclosporin } \\
\text {-Erythropoietin } \\
\text {-Steroids (e.g. prednisolone, hydrocortisone) } \\
\text {-Some cancer therapies }\end{array}$ \\
\hline $\begin{array}{l}\text { Concomitant disease } \\
\text {-HMOD: LVH and/or CKD } \\
\text {-Diabetes } \\
\text {-Atherosclerotic vascular disease } \\
\text {-Aortic stiffening and isolated systolic } \\
\text { hypertension }\end{array}$ & $\begin{array}{l}\text { Uncommon causes } \\
\text {-Phaeochromocytoma } \\
\text {-Fibromuscular dysplasia } \\
\text {-Aortic coarctation } \\
\text {-Cushing's disease } \\
\text {-Hyperparathyroidism }\end{array}$ & $\begin{array}{l}\text { Non-prescription drugs } \\
\text {-Recreational drugs (e.g. cocaine, amphetamines, } \\
\text { anabolic steroids) } \\
\text {-Excess liquorice ingestion } \\
\text {-Herbal remedies (e.g. ephedra, ma huang) }\end{array}$ \\
\hline
\end{tabular}

Figure 27 : Resistant hypertension : recommendations

\section{Recommendations}

It is recommended that hypertension be defined as resistant to treatment (i.e.

resistant hypertension) when:

- Optimal doses (or best-tolerated doses) of an appropriate therapeutic strategy, which should include a diuretic (typically an ACE inhibitor or an ARB with a CCB and a thiazide/thiazide-type diuretic), fails to lower clinic SBP and DBP values to $<140$ $\mathrm{mmHg}$ and/or $90 \mathrm{mmHg}$, respectively; and

- The inadequate control of BP has been confirmed by ABPM or HBPM; and

- After exclusion of various causes of pseudo-resistant hypertension (especially poor medication adherence) and secondary hypertension.

Recommended treatment of resistant hypertension is:

- Reinforcement of lifestyle measures, especially sodium restriction.

- Addition of low-dose spironolactone to existing treatment.

- Or the addition of further diuretic therapy if intolerant to spironolactone, with either eplerenone, amiloride, higher dose thiazide/thiazide-like diuretic, or a loop diuretic.

- Or the addition of bisoprolol or doxazosin. 


\subsection{Secondary hypertension (Figures 28-31)}

Secondary hypertension is hypertension due to an identifiable cause, which may be treatable with an intervention specific to the cause. A high index of suspicion and earl detection of secondary hypertension is important because interventions may be curative, especially in younger patients.

Figure 28: Patients characteristics that should raise the suspicion of secondary hypertension

\begin{tabular}{|l|}
\hline Characteristic \\
\hline $\begin{array}{l}\text { Younger patients (< } 40 \text { years) with grade } 2 \text { hypertension or onset of any grade of } \\
\text { hypertension in childhood }\end{array}$ \\
\hline $\begin{array}{l}\text { Acute worsening hypertension in patients with previously documented chronically stable } \\
\text { normotension }\end{array}$ \\
\hline Resistant hypertension \\
\hline Severe (grade 3 ) hypertension or a hypertension emergency \\
\hline Presence of extensive HMOD \\
\hline Clinical or biochemical features suggestive of endocrine causes of hypertension or CKD \\
\hline Clinical features suggestive of obstructive sleep apnoea \\
\hline Symptoms suggestive of phaeochromocytoma or family history of phaeochromocytoma \\
\hline
\end{tabular}

Figure 29: Commmon causes of secondary hypertension (1)

\begin{tabular}{|c|c|c|c|}
\hline Cause & $\begin{array}{l}\text { Prevalence in } \\
\text { hypertensive } \\
\text { patients }\end{array}$ & Suggestive symptoms and signs & Screening Investigations \\
\hline Obstructive sleep apnoea & $5-10 \%$ & $\begin{array}{l}\text { Snoring; obesity (can be present in non- } \\
\text { obese); morning headache; daytime } \\
\text { somnolence }\end{array}$ & $\begin{array}{l}\text { Epworth score + ambulatory } \\
\text { polygraphy }\end{array}$ \\
\hline $\begin{array}{l}\text { Renal parenchymal } \\
\text { disease }\end{array}$ & $2-10 \%$ & $\begin{array}{l}\text { Mostly asymptomatic; diabetes; haematuria, } \\
\text { proteinuria, nocturia; anaemia, renal mass in } \\
\text { adult polycystic CKD }\end{array}$ & $\begin{array}{l}\text { Plasma creatinine and electrolytes, } \\
\text { eGFR; urine dipstick for blood and } \\
\text { protein, urinary albumin:creatinine } \\
\text { ratio; renal ultrasound }\end{array}$ \\
\hline $\begin{array}{l}\text { Renovascular disease: } \\
\text { Atherosclerotic } \\
\text { renovascular disease }\end{array}$ & $1-10 \%$ & $\begin{array}{l}\text { Older; widespread atherosclerosis (especially } \\
\text { PAD); diabetes; smoking; recurrent flash } \\
\text { pulmonary oedema; abdominal bruit }\end{array}$ & $\begin{array}{l}\text { Duplex renal artery Doppler or } \\
\text { CT angiography or MR angiography }\end{array}$ \\
\hline Fibromuscular dysplasia & & $\begin{array}{l}\text { Younger; more common in women; abdominal } \\
\text { bruit }\end{array}$ & \\
\hline
\end{tabular}


Figure 30: Commmon causes of secondary hypertension (2)

\begin{tabular}{|c|c|c|c|}
\hline Cause & $\begin{array}{c}\text { Prevalence in } \\
\text { hypertensive } \\
\text { patients }\end{array}$ & Suggestive symptoms and signs & Screening Investigations \\
\hline \multicolumn{4}{|l|}{ Endocrine causes: } \\
\hline Primary Aldosteronism & $5-15 \%$ & 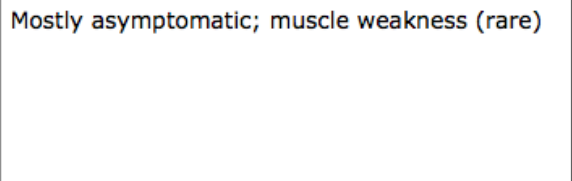 & $\begin{array}{l}\text { Plasma aldosterone and renin, and } \\
\text { aldosterone:renin ratio; } \\
\text { hypokalaemia (in a minority) - note } \\
\text { hypokalaemia can depress } \\
\text { aldosterone levels }\end{array}$ \\
\hline Phaeochromocytoma & $<1 \%$ & $\begin{array}{l}\text { Episodic symptoms - the } 5 \text { 'Ps': paroxysmal } \\
\text { hypertension, pounding headache, perspiration, } \\
\text { palpitations, pallor; labile BP; BP surges } \\
\text { precipitated by drugs (e.g. beta-blockers, } \\
\text { metoclopramide, sympathomimetics, opioids, } \\
\text { and tricyclic antidepressants) }\end{array}$ & $\begin{array}{l}\text { Plasma or 24-h urinary fractionated } \\
\text { metanephrines }\end{array}$ \\
\hline Cushing's syndrome & $<1 \%$ & $\begin{array}{l}\text { Moon face, central obesity, skin atrophy, striae } \\
\text { and bruising; diabetes; chronic steroid use }\end{array}$ & 24-h urinary free cortisol \\
\hline $\begin{array}{l}\text { Thyroid disease (hyper- } \\
\text { or hypothyroidism) }\end{array}$ & $1-2 \%$ & $\begin{array}{l}\text { Signs and symptom of hyper- or } \\
\text { hypothyroidism }\end{array}$ & Thyroid function tests \\
\hline Hyperparathyroidism & $<1 \%$ & Hypercalcaemia, hypophosphatemia & Parathyroid hormone, $\mathrm{Ca}^{2+}$ \\
\hline \multicolumn{4}{|l|}{ Other causes: } \\
\hline Coarctation of the aorta & $<1 \%$ & $\begin{array}{l}\text { Usually detected in children or adolescence; } \\
\text { different BP ( } \geq 20 / 10 \mathrm{mmHg} \text { ) between upper- } \\
\text { lower extremities and/or between right-left arm } \\
\text { and delayed radial-femoral femoral pulsation; } \\
\text { low ABI interscapular ejection murmur; rib } \\
\text { notching on chest X-ray }\end{array}$ & Echocardiogram \\
\hline
\end{tabular}

Figure 31: Medications and substances that may increase blood pressure

\begin{tabular}{|l|l|}
\hline Medication/substance & $\begin{array}{l}\text { Especially oestrogen containing - cause hypertension in 5\% of women, } \\
\text { usually mild but can be severe }\end{array}$ \\
\hline Oral contraceptive pill & For example, phenylpropanolamine and sibutramine \\
\hline Diet pills & For example, phenylephrine hydrochloride and naphazoline hydrochloride \\
\hline Nasal decongestants & $\begin{array}{l}\text { Amphetamine, cocaine, and ecstasy - these substances usually cause acute } \\
\text { rather than chronic hypertension }\end{array}$ \\
\hline Stimulant drugs & $\begin{array}{l}\text { Chronic excessive liquorice use mimics hyperaldosteronism by stimulating } \\
\text { the mineralocorticoid receptor and inhibiting cortisol metabolism }\end{array}$ \\
\hline Liquorice & $\begin{array}{l}\text { For example, cyclosporin A (tacrolimus has less effect on BP and rapamycin } \\
\text { has almost no effect on BP), and steroids (e.g. corticosteroids, } \\
\text { hydrocortisone) }\end{array}$ \\
\hline Antiangiogenic cancer therapies & $\begin{array}{l}\text { Antiangiogenic drugs, such as VEGF inhibitors (e.g. bevacizumab), tyrosine } \\
\text { kinase inhibitors (e.g. sunitinib), and sorafenib, have been reported to } \\
\text { increase BP }\end{array}$ \\
\hline $\begin{array}{l}\text { Other drugs and substances that } \\
\text { may raise BP }\end{array}$ & $\begin{array}{l}\text { Anabolic steroids, erythropoietin, non-steroidal anti-inflammatory drugs, } \\
\text { herbal remedies (e.g. ephedra, ma huang) }\end{array}$ \\
\hline
\end{tabular}




\subsection{Hypertension emergency (Figures 32-33)}

Hypertension emergencies are situations in which severe hypertension (grade 3) is associated with acute HMOD, which is often life-threatening and requires immediate but careful intervention to lower BP, usually with intravenous (i.v.) therapy. The rate and magnitude of increase in BP may be at least as important as the absolute level of BP in determining the magnitude of organ injury

Figure 32: Diagnostic work-up for patients with a suspected hypertension emergency

\begin{tabular}{|l|}
\hline Common tests for all potential causes \\
\hline Fundoscopy is a critical part of the diagnostic work-up \\
\hline 12-lead ECG \\
\hline Haemoglobin, platelet count, fibrinogen \\
\hline Creatinine, eGFR, electrolytes, LDH, haptoglobin \\
\hline Urine albumin:creatinine ratio, urine microscopy for red cells, leucocytes, and casts \\
\hline Pregnancy test in women of child-bearing age \\
\hline Specific tests by indication \\
\hline Troponin, CK-MB (in suspected cardiac involvement, e.g. acute chest pain or acute heart failure) and NT-proBNP \\
\hline Chest X-ray (fluid overload) \\
\hline Echocardiography (aortic dissection, heart failure, or ischaemia) \\
\hline CT angiography of thorax and/or abdomen in suspected acute aortic disease (e.g. aortic dissection) \\
\hline CT or MRI brain (nervous system involvement) \\
\hline Renal ultrasound (renal impairment or suspected renal artery stenosis) \\
\hline Urine drug screen (suspected methamphetamine or cocaine use) \\
\hline
\end{tabular}

Figure 33: Hypertensive emergencies requiring immediate BP lowering with i.v. drug therapy

\begin{tabular}{|l|l|l|l|}
\hline Clinical presentation & $\begin{array}{l}\text { Time line and target for } \\
\text { BP reduction }\end{array}$ & First-line treatment & Alternative \\
\hline $\begin{array}{l}\text { Malignant hypertension with } \\
\text { or without acute renal failure }\end{array}$ & $\begin{array}{l}\text { Several hours } \\
\text { Reduce MAP by } 20-25 \%\end{array}$ & $\begin{array}{l}\text { Labetalol } \\
\text { Nicardipine }\end{array}$ & $\begin{array}{l}\text { Nitroprusside } \\
\text { Urapidil }\end{array}$ \\
\hline Hypertensive encephalopathy & $\begin{array}{l}\text { Immediately reduce MAP by } \\
20-25 \%\end{array}$ & $\begin{array}{l}\text { Labetalol } \\
\text { Nicardipine }\end{array}$ & Nitroprusside \\
\hline Acute coronary event & $\begin{array}{l}\text { Immediate reduce SBP to } \\
<140 \mathrm{mmHg}\end{array}$ & $\begin{array}{l}\text { Nitroglycerine } \\
\text { Labetalol }\end{array}$ & Urapidil \\
\hline $\begin{array}{l}\text { Acute cardiogenic pulmonary } \\
\text { oedema }\end{array}$ & $\begin{array}{l}\text { Immediately reduce SBP to } \\
<140 \mathrm{mmHg}\end{array}$ & $\begin{array}{l}\text { Nitroprusside OR nitroglycerine } \\
\text { (with loop diuretic) }\end{array}$ & $\begin{array}{l}\text { Urapidil } \\
\text { (with loop diuretic) }\end{array}$ \\
\hline Acute aortic dissection & $\begin{array}{l}\text { Immediately reduce SBP to } \\
<120 \mathrm{mmHg} \text { AND heart rate to } \\
<60 \mathrm{bpm}\end{array}$ & $\begin{array}{l}\text { Esmolol AND nitroprusside OR } \\
\text { nitroglycerine OR nicardipine }\end{array}$ & $\begin{array}{l}\text { Labetalol OR } \\
\text { metoprolol }\end{array}$ \\
\hline $\begin{array}{l}\text { Eclampsia and severe pre- } \\
\text { eclampsia/HELLP }\end{array}$ & $\begin{array}{l}\text { Immediately reduce SBP to } \\
<160 \mathrm{mmHg} \text { AND DBP to } \\
<105 \mathrm{mmHg}\end{array}$ & $\begin{array}{l}\text { Labetalol OR nicardipine AND } \\
\text { magnesium sulphate }\end{array}$ & Consider delivery \\
\hline
\end{tabular}


4.7 Treatment recommendations in special situations (Figure 34-42)

Figure 34: White coat and masked hypertension

\section{Management of white-coat hypertension}

\section{Recommendations}

In white-coat hypertensive patients, it is recommended to implement lifestyle changes aimed at reducing $\mathrm{CV}$ risk as well as a regular follow-up with periodic out-of-office BP monitoring.

In patients with white-coat hypertension:

- Drug treatment may be considered in people with evidence of HMOD or in whom CV risk is high or very high.

- Routine drug treatment is not indicated.

Management of masked hypertension

\section{Recommendations}

In masked hypertension, lifestyle changes are recommended to reduce CV risk, with regular follow-up, including periodic out-of-office BP monitoring.

Antihypertensive drug treatment should be considered in masked hypertension to normalize the out-of-office BP based on the prognostic importance of out-of-office BP elevation.

Antihypertensive drug up-titration should be considered in treated patients whose out-of-office $\mathrm{BP}$ is not controlled (i.e. masked uncontrolled hypertension), because of the high $\mathrm{CV}$ risk of these patients. 
Figure 35: Hypertension in pregnancy

\begin{tabular}{|c|}
\hline Recommendations \\
\hline $\begin{array}{l}\text { In women with gestational hypertension or pre-existing hypertension superimposed by } \\
\text { gestational hypertension, or with hypertension and subclinical organ damage or symptoms, } \\
\text { initiation of drug treatment is recommended when SBP is } \geq 140 \text { or DBP } \geq 90 \mathrm{mmHg} \text {. }\end{array}$ \\
\hline $\begin{array}{l}\text { In all other cases, initiation of drug treatment is recommended when SBP is } \geq 150 \mathrm{mmHg} \text { or } \\
\text { DBP is } \geq 95 \mathrm{mmHg} \text {. }\end{array}$ \\
\hline $\begin{array}{l}\text { Methyldopa, labetalol, and CCBs are recommended as the drugs of choice for the treatment } \\
\text { of hypertension in pregnancy. }\end{array}$ \\
\hline ACE inhibitors, ARBs, or direct renin inhibitors are not recommended during pregnancy. \\
\hline $\begin{array}{l}\mathrm{SBP} \geq 170 \mathrm{mmHg} \text { or } \mathrm{DBP} \geq 110 \mathrm{mmHg} \text { in a pregnant woman is an emergency, and } \\
\text { admission to hospital is recommended. }\end{array}$ \\
\hline $\begin{array}{l}\text { In severe hypertension, drug treatment with i.v. labetalol or oral methyldopa or nifedipine is } \\
\text { recommended. }\end{array}$ \\
\hline $\begin{array}{l}\text { The recommended treatment for hypertensive crisis is i.v. labetalol or nicardipine and } \\
\text { magnesium. }\end{array}$ \\
\hline $\begin{array}{l}\text { In pre-eclampsia associated with pulmonary oedema, nitroglycerin given as an i.v. infusion is } \\
\text { recommended. }\end{array}$ \\
\hline $\begin{array}{l}\text { In women with gestational hypertension or mild pre-eclampsia, delivery is recommended at } \\
37 \text { weeks. }\end{array}$ \\
\hline It is recommended to expedite delivery in pre-eclampsia with adverse conditions such as \\
\hline
\end{tabular}

Figure 36: Hypertension in diabetes

\section{Recommendations}

Antihypertensive drug treatment is recommended for people with diabetes when office $\mathrm{BP}$ is $\geq 140 / 90 \mathrm{mmHg}$.

In people with diabetes receiving $\mathrm{BP}$-lowering drugs it is recommended:

- To target SBP to $130 \mathrm{mmHg}$ and lower, if tolerated, but not lower than $120 \mathrm{mmHg}$.

- In older people (aged $\geq 65$ years), to target to an SBP range of 130 to $<140 \mathrm{mmHg}$.

- To target the DBP to $<80 \mathrm{mmHg}$, but not lower than $70 \mathrm{mmHg}$.

It is recommended to initiate treatment with a combination of a RAS blocker with a CCB or thiazide/thiazide-like diuretic.

Simultaneous administration of two RAS blockers, e.g. and ACE inhibitor and ARB, is not indicated. 
Figure 37: Hypertension in CKD

\section{Recommendations}

In patients with diabetic or non-diabetic CKD, it is recommended that an office BP of $\geq 140 / 90 \mathrm{mmHg}$ be treated with lifestyle advice and BP-lowering medication.

In patients with diabetic or non-diabetic CKD:

- It is recommended to lower SBP to a range of $130-139 \mathrm{mmHg}$.

- Individualized treatment should be considered according to its tolerability and impact on renal function and electrolytes.

RAS blockers are more effective at reducing albuminuria than other antihypertensive agents, and are recommended as part of the treatment strategy in hypertensive patients in the presence of microalbuminuria or proteinuria.

A combination of a RAS blocker with a CCB or a diuretic is recommended as initial therapy.

A combination of two RAS blockers is not recommended.

Figure 38: Hypertension in CAD

\section{Recommendations}

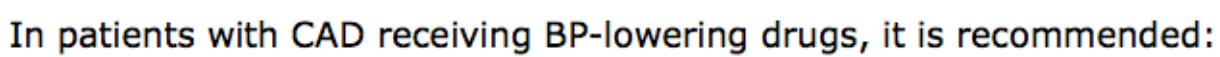

- To target SBP to $130 \mathrm{mmHg}$ and lower, if tolerated, but not lower than $120 \mathrm{mmHg}$.

- In older patients (aged $\geq 65$ years), to target to a SBP range of $130-140 \mathrm{mmHg}$.

- To target DBP to $<80 \mathrm{mmHg}$, but not lower than $70 \mathrm{mmHg}$.

In hypertensive patients with a history of myocardial infarction, beta-blockers and RAS blockers are recommended as part of treatment.

In patients with symptomatic angina, beta-blockers and/or CCBs are recommended. 


\section{Recommendations}

In hypertensive patients with heart failure (with reduced or preserved ejection fraction), BP-lowering treatment should be considered if BP is $\geq 140 / 90 \mathrm{mmHg}$.

In patients with $\mathrm{HFrEF}$, it is recommended that BP-lowering treatment comprises an ACE inhibitor or ARB and a beta-blocker and diuretic and/or mineralocorticoid receptor antagonist if required.

Dihydropyridine CCBs may be added if BP control is not achieved.

In patients with $\mathrm{HFpEF}$, BP-treatment threshold and target values should be the same as for HFrEF.

Because no specific drug has proven its superiority, all major agents can be used.

In all patients with LVH:

- It is recommended to treat with an RAS blocker in combination with a CCB or diuretic.

- SBP should be lowered to a range of $120-130 \mathrm{mmHg}$.

Figure 40: Hypertension and cerebrovascular diseases

\section{Recommendations}

In patients with acute intracerebral haemorrhage:

- Immediate BP lowering is not recommended for patients with $\mathrm{SBP}<220 \mathrm{mmHg}$.

- In patients with $\mathrm{SBP} \geq 220 \mathrm{mmHg}$, careful acute BP lowering with i.v. therapy, to $<180 \mathrm{mmHg}$ should be considered.

In acute ischaemic stroke, routine BP lowering with antihypertensive therapy is not recommended, with the exceptions:

- In patients with acute ischaemic stroke who are eligible for i.v. thrombolysis, BP should be carefully lowered and maintained to $<180 / 105 \mathrm{mmHg}$ for at least the first $24 \mathrm{~h}$ after thrombolysis.

- In patients with markedly elevated BP who do not receive fibrinolysis, drug therapy may be considered, based on clinical judgement, to reduce BP by $15 \%$ during the first $24 \mathrm{~h}$ after the stroke onset.

In hypertensive patients with an acute cerebrovascular event, antihypertensive treatment is recommended:

- Immediately for TIA.

- After several days in ischaemic stroke.

In all hypertensive patients with ischaemic stroke or TIA, a SBP target range of $120-130 \mathrm{mmHg}$ should be considered.

The recommended antihypertensive drug treatment strategy for stroke prevention is a RAS blocker plus a

$\mathrm{CCB}$ or a thiazide-like diuretic. 
Figure 41: Hypertension and atrial fibrillation

\section{Recommendations}

In patients with $A F$, screening for hypertension is recommended.

A beta-blocker or non-dihydropyridine $\mathrm{CCB}$ should be considered as part of the treatment of hypertension if rate control is needed.

Stroke prevention with oral anticoagulation is recommended in patients with $\mathrm{AF}$ and hypertension and a $\mathrm{CHA}_{2} \mathrm{DS}_{2}$-VASc score of $\geq 2$ in men and $\geq 3$ in women. Stroke prevention with oral anticoagulants should be considered in AF patients with hypertension, even when hypertension is the single additional risk factor $\left(\mathrm{CHA}_{2} \mathrm{DS}_{2}\right.$-VASc score of 1$)$.

Oral anticoagulants should be used with caution in patients with marked BP elevation ( $\mathrm{SBP} \geq 180 \mathrm{mmHg}$ and/or $\mathrm{DBP} \geq 100 \mathrm{mmHg}$ ) and the aim should be to lower SBP to at least $<140 \mathrm{mmHg}$ and SBP lowering to $<130$ should be considered. If this is not possible, then patients should make an informed decision that they accept that the stroke protection provided by the anticoagulant will be associated with higher bleeding risk.

Figure 42: Hypertension in perioperative diseases

\section{Recommendations}

It is recommended that newly diagnosed hypertensive patients who are scheduled for elective surgery should be preoperatively screened for HMOD and CV risk.

It is recommended to avoid large perioperative $\mathrm{BP}$ fluctuations during the perioperative period.

Non-cardiac surgery may not be deferred in patients with grade 1 or 2 hypertension ( $\mathrm{SBP}<180 \mathrm{mmHg} ;$ DBP $<110 \mathrm{mmHg}$ ).

Perioperative continuation of beta-blockers is recommended in hypertensive patients on chronic treatment with these drugs.

Abrupt discontinuation of beta-blockers or centrally acting agents

(e.g. clonidine) is potentially harmful and is not recommended.

Transient preoperative discontinuation of RAS blockers should be considered

in patients with hypertension undergoing non-cardiac surgery. 


\section{Follow-up of patients}

\subsection{Frequency of visits}

After the initiation of antihypertensive drug therapy, it is important to review the patient at least once within the first 2 months to evaluate the effects on BP and assess possible side-effects until BP is under control. The frequency of review will depend on the severity of hypertension, the urgency to achieve BP control, and the patient's comorbidities.

Patients with high-normal BP or white-coat hypertension frequently have additional risk factors, including HMOD, and have a higher risk of developing sustained hypertension. Thus, even when untreated, they should be scheduled for regular follow-up (at least annual visits) to measure office and out-of-office BP, as well as to check the CV risk profile.

\subsection{Adherence to therapy (Figure 43)}

There is growing evidence that poor adherence to treatment - in addition to physician inertia (i.e. lack of therapeutic action when the patient's BP is uncontrolled) - is the most important cause of poor BP control. Non-adherence to antihypertensive therapy correlates with higher risk of CV events.

\section{Figure 43: Interventions that may improve drug adherence in hypertension}

\begin{tabular}{|l|}
\hline Physician level \\
\hline Provide information on the risks of hypertension and the benefits of treatment, as well as agreeing a treatment \\
strategy to achieve and maintain BP control using lifestyle measure and a single-pill-based treatment strategy \\
when possible (information material, programmed learning, computer-aided counselling) \\
\hline Empowerment of the patient \\
\hline Feedback on behavioural and clinical improvements \\
\hline Assessment and resolution of individual barriers to adherence \\
\hline Collaboration with other healthcare providers, especially nurses and pharmacists \\
\hline Patient level \\
\hline Self-monitoring of BP (including telemonitoring) \\
\hline Group sessions \\
\hline Instruction combined with motivational strategies \\
\hline Self-management with simple patient-guided systems \\
\hline Use of reminders \\
\hline Obtain family, social, or nurse support \\
\hline Provision of drugs at worksite \\
\hline
\end{tabular}


Drug-treatment level

Simplification of the drug regimen favouring the use of SPC therapy

Reminder packaging

Health-system level

Support the development of monitoring systems (telephone follow-up, home visits, telemonitoring of home BP)

Support financially the collaboration between healthcare providers (pharmacists, nurses)

Reimbursement of SPC pills

Development of national databases, including prescription data, available for physicians and pharmacists

Accessibility to drugs

\section{Note}

The levels of evidence for each of the recommendations presented in the figures can be found in the original publications cited below. Additional figures can also be found in the printed versions of the guidelines.

The grading scale can be found as supplementary material (Supplementary figure 1). 


\section{List of figures:}

Figure 1: Changes in ESC/ESH recommendations between 2013 and 2018

Figure 2: Classification of office BP and definitions of hypertension grades

Figure 3: Evaluation of the CV risk: 10-year cardiovascular risk categories (SCORE)

Figure 4: Risk modifiers increasing CV risk estimated by the SCORE system

Figure 5: Classification of hypertension stages according to BP levels, presence of risk factors, hypertension mediated organ damage (HMOD), or comorbidities

Figure 6: Office BP measurements

Figure 7: Definitions of hypertension according to office, ambulatory, and home BP levels

Figure 8: Advantages and disadvantages of ambulatory blood pressure monitoring and home blood pressure monitoring

Figure 9: Clinical indications for HBPM or ABPM

Figure 10: Screening for hypertension

Figure $11 \mathrm{Key}$ information to be collected in personal and family medical history (1)

Figure 12: Key information to be collected in personal and family medical history (2)

Figure 13: Routine work-up for evaluation of hypertensive patients

Figure 14: Assessments of hypertension mediated organ damage (HMOD)

Figure 15: Initiation of BP-lowering treatment (lifestyle changes and medication at different initial office BP levels

Figure 16: Summary of office BP thresholds for treatment

Figure 17: Office BP treatment targets in hypertensive: recommendations

Figure 18: Life style changes

Figure 19: Core drug-treatment strategy for uncomplicated hypertension

Figure 20: Compelling and possible contraindications to the use of specific antihypertensive drugs

Figure 21: Drug-treatment strategy for hypertension and CAD

Figure 22 Drug-treatment strategy for chronic kidney disease (CKD)

Figure 23 Drug-treatment strategy for hypertension and heart failure with reduced ejection fraction (HRrEF)

Figure 24: Drug-treatment strategy for hypertension and atrial fibrillation (AF)

Figure 25: Treatment targets in special conditions

Figure 26: Resistant hypertension characteristics, secondary causes, and contributing factors

Figure 27: Resistant hypertension: recommendations

Figure 28: Patients characteristics that should raise the suspicion of secondary hypertension

Figure 29: Common causes of secondary hypertension (1)

Figure 30: Common causes of secondary hypertension (2)

Figure 31: Medications and substances that may increase blood pressure

Figure 32: Diagnostic work-up for patients with a suspected hypertension emergency

Figure 33: Hypertensive emergencies requiring immediate BP lowering with i.v. drug therapy

Figure 34: White coat and masked hypertension

Figure 35: Hypertension in pregnancy

Figure 36: Hypertension in diabetes

Figure 37: Hypertension in CKD

Figure 38: Hypertension in CAD

Figure 39: Hypertension in LVH and heart failure

Figure 40: Hypertension and cerebrovascular diseases

Figure 41: Hypertension and atrial fibrillation

Figure 42: Hypertension in perioperative diseases

Figure 43: Interventions that may improve drug adherence in hypertension 


\section{References of original publications:}

1. Williams B, Mancia G, Spiering W, Agabiti Rosei E, Azizi M, Burnier M, Clement DL, Coca A, de Simone G, Dominiczak A, Kahan T, Mahfoud F, Redon J, Ruilope L, Zanchetti A, Kerins M, Kjeldsen SE, Kreutz R, Laurent S, Lip GYH, McManus R, Narkiewicz K, Ruschitzka F, Schmieder RE, Shlyakhto E, Tsioufis C, Aboyans V, Desormais I; ESC Scientific Document Group. 2018 ESC/ESH Guidelines for the management of arterial hypertension. J Hypertension, in press 2018

2. Williams B, Mancia G, Spiering W, Agabiti Rosei E, Azizi M, Burnier M, Clement DL, Coca A, de Simone G, Dominiczak A, Kahan T, Mahfoud F, Redon J, Ruilope L, Zanchetti A, Kerins M, Kjeldsen SE, Kreutz R, Laurent S, Lip GYH, McManus R, Narkiewicz K, Ruschitzka F, Schmieder RE, Shlyakhto E, Tsioufis C, Aboyans V, Desormais I; ESC Scientific Document Group. 2018 ESC/ESH Guidelines for the management of arterial hypertension. European Heart Journal, Volume 39, Issue 33, 1 September 2018, Pages 30213104, https://doi.org/10.1093/eurheartj/ehy339 
Supplementary figure 1: Class of recommendations and levels of evidence as used in the guidelines.

\begin{tabular}{|c|l|l|}
\hline \multicolumn{1}{|c|}{$\begin{array}{c}\text { Classes of } \\
\text { recommendations }\end{array}$} & \multicolumn{1}{c|}{ Definition } & $\begin{array}{c}\text { Suggested wording to } \\
\text { use }\end{array}$ \\
\hline Class I & $\begin{array}{l}\text { Evidence and/or general agreement } \\
\text { that a given treatment or procedure is } \\
\text { beneficial, useful, effective. }\end{array}$ & $\begin{array}{l}\text { Is recommended/ } \\
\text { Is indicated }\end{array}$ \\
\hline Class II & $\begin{array}{l}\text { Conflicting evidence and/or a } \\
\text { divergence of opinion about the } \\
\text { usefullness/efficacy of the given } \\
\text { treatment or procedure. }\end{array}$ & \\
\hline Class IIa & $\begin{array}{l}\text { Weight of evidence/opinion is in } \\
\text { favour of usefulness/efficacy. }\end{array}$ & Should be considered \\
\hline Class IIb & $\begin{array}{l}\text { Usefullness/efficacy is less well } \\
\text { established by evidence/opinion. }\end{array}$ & May be considered \\
\hline Class III & $\begin{array}{l}\text { Evidence or general agreement that } \\
\text { the given treatment or procedure is } \\
\text { not useful/effective, and in some } \\
\text { cases may be harmful. }\end{array}$ & Is not recommendend \\
\hline
\end{tabular}

\begin{tabular}{|l|l|}
\hline $\begin{array}{l}\text { Level of } \\
\text { evidence A }\end{array}$ & $\begin{array}{l}\text { Data derived from multiple randomized } \\
\text { clinical trials or meta-analyses. }\end{array}$ \\
\hline $\begin{array}{l}\text { Level of } \\
\text { evidence B }\end{array}$ & $\begin{array}{l}\text { Data derived from a single randomized } \\
\text { clinical trial or large non-randomized } \\
\text { studies. }\end{array}$ \\
\hline Level of \\
evidence C & $\begin{array}{l}\text { Consensus of opinion of the experts } \\
\text { andior small studies, retrospective }\end{array}$ \\
\hline
\end{tabular}

